\title{
Kościół w życiu Heleny moskiewskiej, żony Aleksandra Jagiellończyka*
}

Tekst do druku przygotował

Adam Kozak

(iD https://orcid.org/0000-0002-7601-5298

Instytut Historii PAN w Poznaniu

\section{Wstęp. Cel pracy}

Helena (ur. 19 maja 1476 roku, zm. 20 stycznia 1513 roku) była jednym z dziewięciorga dzieci Iwana III, wielkiego księcia moskiewskiego (panował w latach 1462-1505), i księżniczki Zoe (ur. ok. 1455 roku, zm. 7 kwietnia 1503 roku) z rodu bizantyńskich Paleologów (była córką Tomasza, despoty Morei

* Niniejszy artykuł stanowi rozszerzoną przez śp. Grażynę Rutkowską (zm. 8 maja 2019 r.) wersję jej referatu wygłoszonego na sesji „Církev ve dvorské společnosti” („Dvory a rezidence ve středověku VI”: Historický ústav Akademie věd České republiky w Pradze, 24-25 listopada 2016 r.). Niestety z uwagi na długotrwałą chorobę i wreszcie śmierć Autorka nie zdołała już ukończyć zaawansowanych prac nad tekstem i przekazać go do druku w materiałach pokonferencyjnych. Pomimo faktu, że rozprawa nie w pełni odpowiada zamierzeniom Autorki G. Rutkowska planowała chociażby zbadanie kwestii podejmowania przez Helenę postów i ewentualnych pielgrzymek oraz zestawienie jej itinerarium, niedokończone wydaje się też zakończenie - to ze względu na wagę tematu udostępniamy tekst szerszej publiczności w obecnym kształcie. W tym miejscu chciałbym złożyć podziękowania Panu Profesorowi Krzysztofowi Pietkiewiczowi za uważne przejrzenie artykułu i zgłoszone uzupełnienia - A.K. 
na Peloponezie, oraz bratanicą Konstantyna IX, ostatniego cesarza Bizancjum) ${ }^{1}$. Helena 15 lutego 1495 roku w Wilnie poślubiła Aleksandra Jagiellończyka, od 1492 roku wielkiego księcia litewskiego i od 1501 roku króla Polski. Była jedyną księżniczką moskiewską, która została żoną Jagiellona. Ich małżeństwo było bezdzietne ${ }^{2}$. Nie została koronowana, ponieważ pozostała przy prawosławnym wyznaniu.

Nie odpowiem na pytanie, czy był to jej świadomy wybór wynikający z żarliwości religijnej, czy posłuszeństwo wobec woli ojca albo obawa przed jego gniewem. Przedstawię natomiast pobożność Heleny, czyli spełniane przez nią, publicznie albo prywatnie, praktyki religijne, doradzane lub zalecane przez prawo kanoniczne. Omówię zatem praktyki obowiązkowe - i te jednorazowe (jak ślub i pogrzeb), i regularne, wynikające ze stale odnawianej przynależności do Cerkwi (udział w nabożeństwach). Spróbuję ustalić, czy Helena podejmowała również pobożne praktyki nadobowiązkowe, wynikające z intensywnego życia religijnego, a może też z przyjętego wzorca zachowania dla prawosławnej księżnej, żony króla (codzienna modlitwa odmawiana indywidualnie, zapewne przed przywiezionymi z domu rodzinnego ikonami, donacje na rzecz świątyń czy monasterów).

Helena swoją osobistą więź z Bogiem praktykowała w obrządku wschodnim, a żyła na polsko-litewskim dworze o ustalonych od dawna codziennych i świątecznych obowiązkach religijnych królewskich pomazańców. Po raz pierwszy nie uczestniczyła w nich małżonka króla. Przyjrzę się zatem, w jaki sposób i w jakim zakresie mogła w Polsce wyznawać swoją wiarę. Zapytam, czy pozostały materialne świadectwa jej pobożności. Spróbuję też objaśnić relacje Heleny z Kościołem łacińskim i jego wyznawcami. Czy była to wzajemna kontestacja, tolerancja, czy akceptacja.

Posłużę się źródłami różnej proweniencji. Helenę wspominali kontynuatorzy Jana Długosza, a więc m.in.: Bernard Wapowski, Maciej z Miechowa, Marcin Bielski, Marcin Kromer i Maciej Stryjkowski³. Informacje o księżnej

${ }^{1}$ W. Dworzaczek: Genealogia. Tablice. Warszawa 1959, tabl. 23.

${ }^{2} \mathrm{O}$ poronionej ciąży Heleny, a może tylko chorobie, zob. K. Pietkiewicz: Wielkie Księstwo Litewskie pod rządami Aleksandra Jagiellończyka. Poznań 1995, s. 166, przyp. 75. Z 15 października 1497 r. pochodzi list matki Heleny, w którym pytała córkę, czy rzeczywiście jest brzemienna i w jakim czasie oczekuje narodzin dziecka (Сборник Императорского Русского Исторического Общества. Т. 35: Памятники дипломатических снотений Московского государства с Польско-Литовским. Т. 1: с 1487 по 1533 год. Ред. Г.Ф. КАРПов. С.-Петербург 1882 (dalej: SRIO), nr 49, s. 241, gdzie pełny tekst listu; reg.: Daniłowicz, T. 2, nr 2102).

${ }^{3}$ Pomijam wydany w 2. poł. XVI w. pod nazwiskiem Aleksandra Gwagnina (włoskiego żołnierza i historyka w służbie polskiej) tom pt. Sarmatiae Europeae descriptio [...], jedno z najbardziej znanych na Zachodzie Europy dzieł historiograficznych czasów nowożytnych mówiących o Polsce. Według najnowszych ustaleń jest to ewidentnie skrócona wersja Kroniki Stryjkowskiego, wykonana na zamówienie panów litewskich i tylko z nieznanych powodów 
przynoszą także: napisana w latach 1532 - 1536 przez Jana z Komorowa Kronika Zakonu Braci Mniejszych Obserwantów, Latopis supraski (tak określana jest Kronika ławry supraskiej), spisany — według jego wydawców — w latach 1740-1748, oraz Pomianik supraski, prowadzony od chwili powstania monasteru, a przepisany z oryginału w 1631 roku. Dalej dokumenty wystawiane przez Helenę oraz jej listy kierowane do kardynała Fryderyka, do jej ojca, matki i braci, potem — już jako wdowy — tylko do brata Wasyla III, wielkiego księcia moskiewskiego (1505-1533), również korespondencja Iwana III kierowana do córki i jej męża, listy Aleksandra do teścia, Iwana III, oraz do brata, Fryderyka, biskupa krakowskiego (od 1488 roku), arcybiskupa gnieźnieńskiego, prymasa i kardynała (od 1493 roku, zm. 1503). Pewne dane przynoszą relacje z podróży do Moskwy np. Mikołaja von Popplau (w literaturze polskiej, i nie tylko, zwanego błędnie Mikołajem z Popielowa), które odbywał jako poseł cesarza Fryderyka III na przełomie 1486 i 1487 roku (ta wizyta, jak sam o niej wspominał, nie była oficjalnym poselstwem cesarskim, a najpewniej tajną misją dyplomatyczną) i na początku 1489 roku (tym razem posiadał pełnomocnictwo cesarskie i listy polecające), a także moskiewska księga poselska, obejmująca m.in. szczegółowe sprawozdanie z podróży Heleny z Moskwy na Litwę, odbytej na początku 1495 roku, i z pierwszego okresu jej pobytu w Wilnie (spisane przez wysłannika Iwana III) ${ }^{4}$. Sięgnę też do latopisów ${ }^{5}$. Zawierają one wprawdzie wiele błędów w chronologii czy w warstwie

pominięto na karcie tytułowej współautorstwo Stryjkowskiego (por. Z. WojTKowiAK: Aleksander Gwagnin i Maciej Stryjkowski dwaj autorzy jednego dzieła. Poznań 2015; rec. A.M. STASIAKA w: „Rocznikach Humanistycznych” 2016, T. 64, z. 2, s. 130-132).

${ }^{4} \mathrm{~W}$ czasach Iwana III zaczęto spisywać w odrębnych księgach akty dyplomatyczne odnoszące się do stosunków z poszczególnymi państwami, m.in. pierwsza z nich obejmowała stosunki z Krymem (od 1474 r.), następne z państwem polsko-litewskim (od 1487 r.), z Rzymem etc. Wpisywano dokumenty, instrukcje poselskie, odpowiedzi udzielane posłom czy zawarte umowy. Księgi poselstw wywieziono do Polski w czasach Dymitra Samozwańca I (1605-1606), część wróciła do Moskwy w 1635 r., pozostałe trafiły do Rosji po rozbiorach (w międzyczasie Naruszewicz przemieszał rękopisy z księgami Metryki Litewskiej). Fragmenty najstarszych ksiąg odnoszących się do stosunków z Polską (w sumie trzy) były wydawane m.in. przez Dogiela, Muchanova czy w Aktach Zapadnoj Rossii, a pełne wydanie otrzymały w SRIO, T. 35.

${ }^{5}$ Dokonałam wyboru, w zasadzie cytuję tylko Latopis sofijski I, Kronikę Bychowca i Latopis hustyński. Najstarsze zwody powstawały w księstwie moskiewskim od 1472 r., w czasach Iwana III, i ich podstawą był właśnie Latopis sofijski I, a więc współczesny opisywanym wydarzeniom i prezentujący oficjalną wersję zdarzeń (wyd.: Полное собрание русских летописей. Т. 6. Санктпетербургъ 1853). Natomiast spisana w końcu XVI lub na początku XVII w. Kronika Bychowca, jedna z trzech redakcji Latopisu Wielkiego Księstwa Litewskiego $i$ Żmudzkiego, reprezentuje odmienną tradycję. Autorem całości lub części był prawosławny Rusin z Litwy. Wieńczyła ona „długi proces redagowania litewsko-ruskich latopisów i kronik [...], jako całość powstała w kręgu Gasztołdów i spokrewnionych z nimi Holszańskich i Olelkowiczów-Słuckich" (O. ŁatyszoneK: Polityczne aspekty przedstawienia średniowiecznych dziejów ziem białoruskich w historiografii Wielkiego Księstwa Litewskiego w XV-XVI w. 
faktograficznej, jednak informacje w nich podane można skonfrontować z innymi, niezależnymi źródłami.

Osoba Heleny od dawna cieszyła się zainteresowaniem badaczy, ale powstała na jej temat tylko jedna monografia, napisana jeszcze w XIX wieku i nieodpowiadająca wymogom współczesnej historiografii ${ }^{6}$. Opublikowano interesujący biogram księżnej pióra Józefa Garbacika w Polskim słowniku biograficznym oraz szereg artykułów? ${ }^{7}$ Uwagę przyciągają teksty ukazujące się

„Białoruskie Zeszyty Historyczne. Беларускі гістарычны зборнік” 2006, Т. 25, s. 20). Zdecydowałam się sięgnąć też do Latopisu hustyńskiego z XVII w., uważanego za pierwszy latopis ukraiński, ze względu na to, że reprezentuje on z kolei piśmiennictwo ukraińskie, a stosunkowo niedawno otrzymał, tak jak Kronika Bychowca, nową, krytyczną edycję (H. Suszko: Latopis hustyński. Opracowanie, przektad i komentarze. Wrocław 2003). Wydawca pisał, że autor tego latopisu czerpał wiadomości przede wszystkim z polskich źródeł, a więc kronik Długosza i jego kontynuatorów, ale nie jest to „typowa kompilacja, ponieważ odznacza się ona swoistym objaśnianiem faktów zaczerpniętych z różnych źródeł i własnym spojrzeniem autora na historię" (tamże, s. 19). Wśród zdarzeń godnych odnotowania nie znalazła się w latopisie np. bitwa pod Grunwaldem, ponieważ dla dziejów narodu ukraińskiego nie było to pewnie wydarzenie najważniejsze, ale kilkakrotnie wspomniano Helenę, żonę Aleksandra Jagiellończyka. O latopisach zob. też S. Polechov (Wielkie Księstwo Litewskie i Królestwo Polskie za czasów Jagiełty $i$ Witolda $w$ latopisarstwie ruskim. „Zeszyty Naukowe Uniwersytetu Jagiellońskiego. Prace Historyczne" 2014, T. 141, z. 2, s. 583-597), który podkreślał (s. 589): „[...] latopisy powstawały przy katedrach biskupich lub nawet na dworze metropolity, a położenie Cerkwi prawosławnej w Wielkim Księstwie Litewskim było bardzo specyficzne ze względu na jej podporządkowanie interesom panującej mniejszości katolickiej [...], źródłami wiedzy latopisarzy ruskich o Wielkim Księstwie Litewskim były z reguły informacje ustne otrzymywane od uczestników lub świadków wydarzeń - przybywających z Litwy książąt, metropolitów, biskupów i towarzyszących im osób, kupców itd.”.

${ }^{6}$ Е. ЦеРЕтЕЛИ: Елена Иоанновна великая княгиня литовская, русская, королева полская. С. Петербургъ 1898. F. РАРÉE w recenzji (Kw. Hist. 1900, T. 14, s. 310-313) napisał o tej książce, że „najlepiej gdyby została w tece”, zarzucając autorce brak krytyki, pogłębienia analiz i „powiew szkolnego oficjalnego patriotyzmu” (tamże, s. 311). Warto przypomnieć, że wcześniej, bo w 1847 r., J. Bartoszewicz wydał rozprawę pt. Helena Iwanowna żona Aleksandra Jagiellończyka, ale pomimo pozwolenia cenzury cały nakład Biblioteki Warszawskiej skonfiskowano i zniszczono (Z. Gloger: Julian Bartoszewicz 1821-1870. W: TenżE: Pisma rozproszone. T. 1: 1863-1876. Red. J. ŁaWski, J. LeoŃCZUK. Białystok 2014, s. 400; zob. też Z. ZielińsKa-KLimkiewicz: Księgozbiór Bartoszewiczów - przeszłość i teraźniejszość. „Acta Universitatis Lodziensis. Folia Librorum" 1998, T. 8, s. 70). Chyba ta praca została pośmiertnie wydana nakładem K. Bartoszewicza (wydawca ogólnie informował w nocie od wydawcy, że publikuje przedruki, a artykuł o Helenie opatrzył datą 1847 r.): J. BARToszewicz: Helena Iwanowna, żona Aleksandra Jagiellończyka. W: TenżE: Studia historyczne i literackie. T. 1. Kraków 1880, s. 9-72 (Dzieła Juliana Bartoszewicza, T. 8).

7 J. GarbaciK: Helena (1476-1513), żona Aleksandra Jagiellończyka. W: PSB, T. 9, s. 359-362; Н. ЕлАгин: Елена Иоанновна, великая княгиня Литовская и королева Польская. „Журнал Министерства народного просвещения” 1846, Т. 50, № 4, отд. 2, s. 39-84; М.Н. Бережков: Елена Ивановна, великая княгиня литовская и королева польская. В: Труды IX археологическаго съезда въ Вильне 1893. Т. 2. Москва 1897, s. 1-44; Я.С. ЛурьЕ: Елена Ивановна, королева Польская и великая княгиня Литовская 
w prasie czy w czasopismach wydawanych przez polską społeczność prawosławną. Są wartościowe nie tylko z naukowego punktu widzenia. Świadczą one o przechowaniu w zbiorowej pamięci postaci Heleny jako szanowanej ktitorki Cerkwi i jej wyznawców. Wystarczy przejrzeć prawosławną prasę, np. ogólnopolski miesięcznik „Przegląd Prawosławny”, „Biuletyn Informacyjny" Bractwa Prawosławnego św. św. Cyryla i Metodego (wydawane w Białymstoku) i „Над Бугом и Нарвою. Український часопис Підляшшя” (publikowany w Bielsku Podlaskim), oraz działający od 2002 roku internetowy serwis www.cerkiew.pl (prowadzi go Stowarzyszenie Prawosławna Inicjatywa OrthNet z siedzibą w Białymstoku). W nich zamieszczane są teksty o dokonaniach Heleny. Wzorce zachowania czy wartości, które sobą reprezentowała, uznano za ważne i godne utrwalenia. Szczególną czcią w Polsce otoczone są ikony Bogurodzicy, które - według tradycji — księżna ofiarować miała podlaskim cerkwiom w Bielsku, Brańsku i Supraślu.

\section{Rola prawosławia w doktrynie państwowej Księstwa Moskiewskiego w czasach Iwana III}

Omówię ten temat, by zrozumieć powody, dla których Iwan III konsekwentnie nie zgadzał się na przyjęcie przez jego córkę chrztu w obrządku łacińskim lub przynajmniej uznanie przez nią prymatu papieża. Helena nie spełniła warunków stawianych jej przez stronę polską i tym samym nie mogła zostać koronowana, ponieważ byłoby to sprzeczne z polskim zwyczajem. Mogłoby być uproszczeniem uznanie, że w Moskwie nie rozumiano, jak silne i różnorakie były powiązania między sacrum i profanum w państwach oraz społeczeństwach łacińskich. Może Iwan III zamierzał poprzez małżeństwa swoich córek i synów budować w Europie przyczółki prawosławia? Ten zamiar, jeśli był, nie powiódł się. Skłaniam się do myśli, że dla Iwana III ważniejszy od koronacji jego córki był realizowany przez niego program polityczny, skierowany do własnych poddanych, innych książąt ruskich i dworów europejskich.

Ojciec Heleny nie był jednym z wielu Rurykowiczów władających małym księstwem i walczących o przetrwanie ${ }^{8}$. Iwan III był władcą, który kontynuкак писатель-публицист. „Canadian-American Slavic Studies” 1979, Vol. 13, no 1-2, s. $111-120$.

${ }^{8}$ Temat obrósł w ogromną literaturę. Podaję tu wybór: Н.М. КАРАмзин: История государства Российского. Т. 5-6. Москва 1818 (N.M. KARAmzin: Historya państwa rossyiskiego M. Karamzina. Tłum. G. BuczyŃsKi. T. 5-6. Warszawa 1825-1826); A.В. КАРTAшеB: 
ował działania swoich poprzedników (od czasów Iwana Kality, księcia moskiewskiego w latach 1325-1340) i realizował trzy główne cele: wewnętrzne wzmocnienie księstwa, skupienie wokół Moskwy całości ziem ruskich i uniezależnienie od Ordy. Odniósł sukces, ponieważ dokonał ostatecznego zjednoczenia Rusi, rozpoczął proces budowy państwa scentralizowanego i suwerennego, zlikwidował większość księstw udzielnych, których władcy zasilili szeregi bojarów moskiewskich, wyeliminował innych pretendentów do władzy z grona własnej rodziny czy z rodów książąt ruskich, podporządkował sobie Cerkiew, zorganizował służbę dyplomatyczną, wprowadził państwo na arenę europejską jako równorzędnego partnera, z wyraźnie jednak, dzięki prawosławiu, akcentowaną odrębnością i niezależnością. Najpierw priorytet stanowiło przyłączenie do Moskwy tej części Rusi, która pozostawała poza granicami Polski i Litwy (zajął księstwo jarosławskie i republikę pskowską w 1463 roku, księstwa dmitrowskie oraz możajskie i sierpuchowskie po 1472 roku, kupił księstwo rostowskie w 1474 roku, w 1478 roku przyłączył Nowogród Wielki, a w 1485 roku Twer, wreszcie uzależnił Wiatkę w 1489 roku i Riazań w 1503 roku). Następnie, już po śmierci króla i hospodara Kazimierza Jagiellończyka (zm. 1492), podjął otwartą walkę z Litwą o ziemie dawnej Rusi Kijowskiej, występując jako obrońca prawosławia, prześladowanego na Litwie jak twierdził - przez Kościół łaciński. W dwóch wojnach toczonych w latach 1492 - 1494 i 1500 - 1503 zajął prawie 1/3 obszaru Wielkiego Księstwa Litewskiego (przyłączając księstwa wierchowskie, ziemie czernihowsko-siewierskie, wschodnią Smoleńszczyznę i Toropiec). Iwan III, po ślubie z Zoe (w 1472 roku, wtedy przybrała imię Zofia), wprowadził na rewersie swojej pieczęci wizerunek dwugłowego orła ${ }^{9}$. W kontaktach z Aleksandrem Jagiellończykiem uży-

Очерки по истории русской церкви. Париж 1959; A. KRUPSKA: Z dziejów tworzenia się nowego uktadu politycznego w Europie Wschodniej po upadku Złotej Ordy w XV wieku. Rocz. Hist. 1976, T. 42, s. 31-81; А.Л. Хорошкевич: Русское государство в системе международных отношений конща XV - начала XVI в. Москва 1980; История Русской православной Церкви в документах региональных архивов России. Ред. Архимандрит И. Просвирнин. Москва 1993; W. Peltz: Suwerenność państwa w praktyce i doktrynie politycznej Rusi Moskiewskiej (XIV—XVI w.). Zielona Góra 1994; K. Снолnicka: Narodziny rosyjskiej doktryny państwowej. Zoe Paleolog — między Bizancjum, Rzymem a Moskwa. Kraków 2001; Р.Г. Скрынников: Иван III. Москва 2006; М.М. Кром: Меж Русью и Литвой. Пограничные земли в системе русско-литовских отномений конца XV - первой трети XVI в. Москва 2010; K. Волко: Stosunki dyplomatyczne Moskwy z Europa Zachodniq w czasach Iwana III. Kraków 2010; A. MironowicZ: Cerkiew prawosławna w dziejach Rosji. W: Wprowadzenie do studiów wschodnioeuropejskich. T. 3: Rosja. Red. A. Mironowicz. Lublin 2013, s. 88-129 (tamże dalsza literatura).

${ }_{9}$ Wizerunku tego użyto po raz pierwszy w 1497 r., stąd wydaje się, że nie odnosił się on do godła Paleologów, a jego wykorzystanie powiązane było z uzależnieniem Tweru, gdzie symbol orła występował na monetach, a zatem miał on być pewnie przesłaniem skierowanym do książąt ruskich, że znajdują się w moskiewskiej sferze wpływów (K. CHoJNickA: Narodziny..., s. 129-131). W literaturze nie wyklucza się jednak, że Iwan III zwrócił uwagę na 
wał tytułu wielkiego księcia, czasem też gosudara i samodzierżcy, uzupełniając go określeniem: wszystkiej Rusi (wsieja Rusi) ${ }^{10}$. Z kolei w korespondencji dyplomatycznej podkreślał związki genealogiczne przede wszystkim z Rzymem, sporadycznie zaś z Bizancjum. Te elementy jego programu politycznego mówiły o powstaniu kraju niezależnego od papiestwa i równouprawnionego wśród monarchii europejskich. Trzeba podkreślić, że Europa końca XV wieku wiedziała wprawdzie o nowym państwie, ponieważ na Zachód przenikały informacje dyplomatów, kupców i podróżników docierających do Moskwy, ale z Moskwy do Europy wysyłano wiadomości starannie wyselekcjonowane. Posłowie Iwana III jechali na obce dwory ze szczegółowymi instrukcjami, co mają mówić i jak się zachowywać — a mówili o prawdziwych lub zmyślonych sukcesach Iwana III nad Litwą i Tatarami czy obiecywali udział w lidze antytureckiej. Każde zaś uchybienie wobec siebie (a więc np. posadzenie ich nie w pierwszym rzędzie, a wśród innych posłów) musieli traktować jak znieważenie samego Iwana III i byli zobowiązani natychmiast opuścić zgromadzenie.

Program państwowy nie był formułowany w kręgach cerkiewnych. To wyłącznie władca moskiewski decydował o stosunkach międzynarodowych, traktatach, wojnach, reformach gospodarczych, wojskowych czy państwowych. Cerkiew zaś w niepewnych czasach po upadku Konstantynopola (1453) szukała opieki państwa i zainteresowana była powstaniem silnej monarchii. Iwan III dokonywał nominacji metropolity moskiewskiego, kierując się wyborem synodu ${ }^{11}$. Doktrynie państwowej, a nie umocnieniu hierarchii cerkiew-

godło Maksymiliana I i orzeł cesarski z czasem zastąpił wcześniejszy herb, przedstawiający św. Jerzego Zwycięzcę walczącego ze smokiem (ostatnio M. Mazuś: Koncepcje ideologiczne „Moskwa - III Rzym” oraz „Kijów - II Jerozolima” w ujęciu porównawczym. „Slavia Orientalis” 2015, T. 64, nr 3, s. 465, zdecydowanie pisze, że „Jednym z najistotniejszych przejawów zaadaptowania spuścizny Cesarstwa Bizantyjskiego było przyjęcie przez Moskwę dwugłowego orła jako godła”).

${ }^{10}$ Iwan III po raz pierwszy użył tytułu gosudara całej Rusi w korespondencji dyplomatycznej z Polską 6 lutego 1493 r. (list do Aleksandra Jagiellończyka: Lietuvos Metrika (14271506). Knyga Nr. 5. Užrašymu knyga 5. Vilnius 1993 (dalej: LM 5), s. 67 = Daniłowicz, T. 2, $\mathrm{nr} 2055$ ). Reakcja była natychmiastowa: rada litewska wystosowała 20 lutego tego roku list do wojewody moskiewskiego, kniazia Iwana Jurewicza, zwracając uwagę, że Iwan III w swoim liście użył tytułu niezgodnego z dawnym zwyczajem, i prosiła, by zwrócił na to uwagę swojemu władcy (LM 5, s. 68 = Daniłowicz, T. 2, nr 2058). Tytuł gosudara całej Rusi wszedł na stałe do tytulatury Iwana III (1493 r.: LM 5, s. 80; 1495 r.: tamże, s. 88, 91; 1496 r.: tamże, s. 98, 99, 114; 1498 r.: tamże, s. 134 itd.). Tytuł ten, pochodzący od polskiego słowa „gospodarz”, użyty po raz pierwszy przez Kazimierza Wielkiego w jego ruskich aktach, pojawił się w Moskwie w połowie XV w., przejęty z Litwy. Wasyl II w latach 1448 - 1449 tytułował się na monetach (2)осподарь всея Руси lub (2)осподарь русскои земли. Od skrótu spółgłoskowego гсдр роwstało rosyjskie słowo государь — 'władca' (А. Золтан: К предыстории русск. «государь». В: Из истории русской культуры. Т. 2. Москва 2002, s. 554-590). Tytuł wielkoksiążęcy władcy Moskwy przyswoili sobie w XIV w.

${ }_{11}$ W 1458 r. patriarcha Konstantynopola Grzegorz III, w porozumieniu z papieżem Piusem II i królem Kazimierzem Jagiellończykiem, mianował metropolitą kijowskim 
nej, służyły deklaracje o prawosławiu jako wyznaniu dominującym w Księstwie Moskiewskim i o kraju, który jako jedyny po upadku Konstantynopola roztoczył opiekę nad wyznawcami prawdziwego Kościoła Chrystusowego, zagrożonego przez muzułmańskich Turków i Tatarów oraz przez zachodnie chrześcijaństwo, zwłaszcza przez Polskę, Litwę i zakon krzyżacki. Argumenty te pojawiły się już w żądaniach Iwana III skierowanych do jego przyszłej żony Zoe ${ }^{12}$, a po latach też córki Heleny, wydanej za mąż za Aleksandra Jagiellończyka, by obie oddane były wierze greckiej. Pełne wsparcie hierarchii cerkiewnej Iwan III zapewnił sobie w 1503 roku, gdy po latach niepewności, czy majątki cerkiewne nie zostaną skonfiskowane przez księcia, sobór określił dobra nieruchome Cerkwi jako święte i niezbywalne. Uchwały tej nie można było podjąć bez zgody Iwana III, który w ten sposób zyskał oddanie hierarchów i ich całkowitą zależność od władzy świeckiej. To zresztą duchowni prawosławni stanowili kadry dla powstającej w czasach tego księcia służby dyplomatycznej, administracyjnej i urzędniczej.

Grzegorza II Bułgara (zwolennika unii florenckiej). Doszło wówczas do ostatecznego podziału metropolii ruskiej na część moskiewską ze stolicą w Moskwie i kijowską (litewską) w granicach państwa Jagiellonów. Z kolei wybór w $1461 \mathrm{r}$. Teodozjusza na nowego metropolitę moskiewskiego (nie zabiegano o decyzję patriarchy Konstantynopola: wskazany został na następcę przez swojego poprzednika Jonasza, zatwierdzony przez synod biskupów i zaaprobowany przez księcia moskiewskiego) potwierdzał odrębność Cerkwi Rusi północno-wschodniej i świadczył o odrzuceniu wszelkich form zwierzchnictwa Rzymu. Spór o podział metropolii zakończył się w 1480 r. po wyborze na metropolitę kijowskiego Symeona Rusina (zwanego Szymonem). Biskupi moskiewscy zrezygnowali wówczas z tytułu metropolitów kijowskich i z podporządkowania sobie biskupstw litewskich, z kolei zwierzchnicy metropolii kijowskiej przyjęli tytuł metropolitów kijowskich oraz halickich i nie zabiegali o władzę nad Kościołem w Moskwie (K. Chodynicki: Kościót prawosławny a Rzeczpospolita Polska. Zarys historyczny 1370-1632. Warszawa 1934, s. 62 -68; T.M. Trajdos: Metropolici kijowscy Cyprian i Grzegorz Camblak a problem Cerkwi prawosławnej w państwie polsko-litewskim u schyłku XIV $i$ w pierwszej ćwierci $X V$ w. „Balcanica Posnaniensia” 1985, T. 3, s. 211-233; A. MiroNowicz: Organizacja Kościoła prawosławnego w Rzeczypospolitej do końca XVIII wieku. W: Europa orientalis. Polska i jej wschodni sassiedzi od średniowiecza po wspótczesność. Studia $i$ materiaty ofiarowane profesorowi Stanisławowi Alexandrowiczowi w 65. rocznice urodzin. Red. nauk. Z. Karpus, T. Kempa, D. Michaluk. Toruń 1996, s. 212-213; J. Kuligowski: Kościót Wschodni na Ziemi Chetmskiej i potudniowym Podlasiu od chrystianizacji do końca XVI wieku. „Rocznik Mazowiecki” 2000, T. 12, s. 50).

${ }^{12}$ Latopis nikonowski (późny kompilacyjny moskiewski zwód), spisany w końcu lat 50. XVI w. (w literaturze podawany jest także XVII w., tu podaję datę za: Б.М. КлосС: Никоновский свод и русские летописи XVI-XVII веков. Москва 1989; Летопись Никоновская. В: Словарь книжников и книжности Древней Руси. Т. 2 (вторая половина XIV-XVI в.). Ч. 2: Л—Я. Ленинград 1989, s. 49—50), opisywał — niewątpliwie mało wiernie — starania papiestwa, by Zofia poślubiła Iwana III: wcześniej odrzuciła ona propozycję małżeństwa z królem Francji, ponieważ niechętna była zachodniemu wyznaniu, przyjęła natomiast starania księcia moskiewskiego, po upewnieniu się, że on i jego poddani są wyznawcami prawosławia (Полное собрание русских летописей. Т. 12. С.-Петербургъ 1901, s. 120, 142, 143, 147, 148, $150-152,246,263)$. 
Matka Heleny, Zoe, w 1460 roku opuściła Moreę (po opanowaniu jej przez Turków) i po kilku latach tułaczki znalazła schronienie wraz z matką i braćmi w Rzymie (w 1465 roku) pod opieką papieży Pawła II, potem Sykstusa IV, którzy uważali ją, podobnie jak jej ojca, za zwolenniczkę unii florenckiej i podporządkowania Kościoła wschodniego prymatowi papieża. Może wychowywana była tu w wierze zachodniej, ponieważ na dworze Paleologów w Rzymie opiekujący się nimi kardynał Bessarion zainstalował dwóch duchownych łacińskich ${ }^{13}$. Zofia, jeśli została łacinniczką, to była nią tylko w Rzymie. W Moskwie manifestowała swoje przywiązanie do prawosławia i nie podjęła żadnych działań na rzecz jedności Kościoła wschodniego z Rzymem czy wciągnięcia męża w sojusz antyturecki. Nie ma żadnych przesłanek, by sądzić, że prowadziła w państwie moskiewskim jakąkolwiek samodzielną aktywność polityczną (poza krótkim epizodem, gdy popadła w niełaskę, broniąc praw syna Wasyla do schedy po ojcu). Cesarskie i bizantyjskie pochodzenie Zofii w Moskwie czasem eksponowano (tak można zrozumieć napis wyszyty na pelenie, czyli tkaninie, którą Zofia kazała wyhaftować lub może sama wykonała w 1499 roku i tam nazwała siebie carewną carogrodzką, a nie wielką księżną moskiewską) ${ }^{14}$. Także w latopisach spotykamy niekiedy informacje, że była córką Tomasza Paleologa, despoty Peloponezu (nieściśle, ponieważ był despotą Morei $)^{15}$. Jednak ani ona, ani Iwan III nie aspirowali do schedy po Paleologach (zwłaszcza że żyli bracia Zofii), nie podejmowali działań i rozmów dyplomatycznych na ten temat, ponieważ Moskwa nie była zainteresowana wyniszczającą walką z potęgą turecką o odległy Konstantynopol (ten fakt na dworach europejskich zrozumiano dopiero w latach 90. XV wieku, choć jeszcze na początku XVI stulecia łudzono się, że Moskwa weźmie udział w krucjacie antytureckiej).

Prawosławie było zatem jednym z kluczowych punktów programu państwowego Iwana III, nadzwyczaj inteligentnie włączonym w całość dokonywanych w Moskwie przemian, także społecznych, czy w program zbierania ziem ruskich. Tracący na znaczeniu bojarzy i książęta służebni, również szeregowi dworianie służący w wojsku, otrzymywali od wielkiego księcia, zamiast dotychczasowych wotczin (dóbr dziedzicznych), pomiestije (niezbywalne dobra

${ }^{13}$ K. Chojnicka: Narodziny..., s. 50-53.

14 Tkanina (tafta, rozmiar $103 \times 122 \mathrm{~cm}$ ) przechowywana była w ławrze Troicko-Siergijewskiej w mieście Siergijew Posad (70 km na północ od Moskwy), obecnie znajduje się w muzeum powstałym w 1920 r. na terenie ławry. Peleny zawieszano pod ikonami jako wyraz szczególnej czci, towarzyszyły ikonom podczas procesji (А.С. Петров: Шитый образ под иконой. Изображения на подвесных пеленах. В: Церковное шитьё в Древней Руси. Ред. Э.С. Смирнов. Москва 2010, s. 69-81).

${ }_{15} \mathrm{~Np}$. Latopis ipatiewski z początku XV w., sporządzony prawdopodobnie w Pskowie (Полное собрание русских летописей. Т. 2. 1-е изд. Санктпетербургъ 1843, s. 364 = Scriptores rerum Polonicarum. T. 2. Kraków 1872, s. 304), oraz hustyński (H. Suszko: Latopis hustyński..., s. 221). 
ziemskie w zamian za służbę na rzecz władcy), które tracili po opuszczeniu ziem moskiewskich. Ci zaś, którzy wyjechali z Moskwy i zamieszkali na stałe zwłaszcza na Litwie, traktowani byli jak zdrajcy i odstępcy od prawdziwej wiary (choć formalnie nie zniesiono prawa odjazdu ${ }^{16}$ ).

Despotycznie rządzone Wielkie Księstwo Moskiewskie Iwana III sąsiadowało $\mathrm{z}$ wielkim organizmem państwowym polsko-litewskim, o silnych instytucjach samorządowych i słabnącej władzy centralnej, usiłującym - bez powodzenia - stworzyć system dynastyczny. Rządy Jagiellonów na Węgrzech okazały się krótkimi epizodami w latach 1440-1444 (Władysław III, syn Władysława Jagiełły) i od 1490 roku tamże, podobnie jak wcześniej od 1471 roku w Czechach i na Morawach (Władysław, syn Kazimierza Jagiellończyka, potem zaś Ludwik poległy pod Mohaczem w 1526 roku). Państwo polskie zdolne było do realizowania zadania obrony własnych ziem do chwili najazdu Moskwy na ziemie litewskie. Wówczas zawiodła dyplomacja, jakby nieświadoma powstania silnego i agresywnego sąsiada. Zlekceważono sojusz Moskwy z Chanatem Krymskim, a w październiku 1480 roku wydarzenia nad rzeką Ugrą: wojska Wielkiej Ordy, dowodzone przez chana Achmata, nie otrzymały obiecanych przez Kazimierza Jagiellończyka posiłków litewskich i w rezultacie od tego roku rozpoczął się proces wyzwalania Moskwy spod jarzma tatarskiego (Iwan III nigdy jednak nie zerwał z Tatarami, zachował fikcję swojej zależności, uznając chana krymskiego Mengli Gireja, pogromcę Achmata, za swojego suzerena, a zarazem skierował go przeciwko Jagiellonom). Potem Moskwa mogła już skupić się na kolejnych celach, a zwłaszcza na zbieraniu ziem ruskich.

Polska od tej chwili musiała liczyć się z realnym zagrożeniem najazdami sojuszników Moskwy, czyli wspomnianego Mengli Gireja i Stefana III Wielkiego, hospodara wołoskiego (Iwan Młody, zmarły w 1490 roku najstarszy syn Iwana III, był mężem córki Stefana, Heleny). Moskwa końca XV i początku XVI wieku zawsze w swoich działaniach wyprzedzała Rzeczpospolitą, realizując konsekwentnie i niespiesznie własne cele strategiczne, a jej uwagę absorbując np. antyjagiellońskimi projektami współpracy z Maciejem Korwinem czy z Habsburgami, a w końcu długimi negocjacjami w sprawie małżeństwa Heleny z Aleksandrem Jagiellończykiem.

${ }^{16}$ T. TARANOwsKi: Historia prawa rosyjskiego. Cz. 1: Historia ustroju państwowego. Lwów 1928, s. 37. 


\section{Polskie i europejskie zwyczaje obowiązujące przy ślubie książąt i królów $z$ osobami prawosławnego wyznania}

Pertraktacje w sprawie małżeństwa Heleny z Aleksandrem rozpoczęły się w 1484 roku (rozmową kniazia Iwana Juriewicza Patrikiewicza z litewskim marszałkiem dworskim Janem Zabrzezińskim, niewątpliwie podjętą z polecenia władcy moskiewskiego) i kontynuowane były po przerwie od 1490 roku już z inicjatywy strony polsko-litewskiej ${ }^{17}$. W literaturze zgodnie uważa się, że chodziło o odsunięcie od Litwy groźby najazdów Moskwy i jej sojuszników. Iwan III domagał się pozostania Heleny po ślubie przy wierze prawosławnej, budowy dla niej cerkwi na zamku wileńskim, utrzymywania przy księżnej jej prawosławnego dworu oraz zaprzysiężenia przez wielkiego księcia litewskiego traktatu pokojowego, w którym Litwa musiała pogodzić się z zajęciem przez Moskwę Wiaźmy (w 1493 roku) i księstw wierchowskich ${ }^{18}$. Negocjacje kończył list Aleksandra Jagiellończyka z października 1494 roku, w którym po raz kolejny zapewniał Iwana III, że jego córka będzie mogła zostać przy wyznaniu greckim $^{19}$. Żądania pozostania Heleny przy wschodnim wyznaniu oraz budowy dla niej cerkwi na zamku w Wilnie pojawiały się potem jeszcze wielokrotnie, zarówno przed zawarciem małżeństwa, jak i później, także w okresie jej wdowieństwa, a nawet były oficjalnym powodem najazdów Moskwy na Litwę (Wasyl III, brat Heleny, posłużył się tymi argumentami, szykując się do wojny

17 F. Koneczny: Litwa a Moskwa w latach 1449-1492. Wilno 1929, s. 201 (o rozmowach z 1484 r.). Dalsze negocjacje zapoczątkował list z kwietnia 1490 r. Filipa Kallimacha, włoskiego humanisty przebywającego w Polsce, do Zofii Paleolog, w którym doradzał małżeństwo jej córki z pretendującym do tronu węgierskiego Janem Olbrachtem (Z. SPIERAlski: Zofia Paleolog adresatka listu Kallimacha. „Odrodzenie i Reformacja w Polsce” 1978, T. 23, s. 189-198). Sądzić można, że list wysłał co najmniej za wiedzą dworu krakowskiego. Potem, wkrótce po śmierci Kazimierza Jagiellończyka, panowie litewscy wysłali do wojewody nowogrodzkiego posła, który 14 lipca 1492 r. dostarczył list. Rada litewska ponawiała w nim projekt mariażu córki Iwana z Aleksandrem (SRIO, T. 35, nr 17, s. 71). Negocjacje przedstawiła szczegółowo A. Winiarska: Rola Heleny Rurykowiczówny w świetle stosunków litewsko-moskiewskich na przełomie XV i XVI w. „Rocznik Naukowo-Dydaktyczny WSP w Krakowie. Prace Historyczne" 1968, T. 4, s. 5-29; zob. też K. Волко: Stosunki..., s. 110-122 і М.Н. БЕРЕжКов: Елена Ивановна..., s. 5-11 (na s. 5-6 o poselstwie Konrada mazowieckiego do Iwana III z propozycją małżeństwa z jedną z córek księcia moskiewskiego; odpowiedź Iwana III nie jest znana).

18 Długie negocjacje, wymiana poselstw, toczyły się w styczniu i lutym 1494 r. — traktat pokojowy oraz wzór aktu, jaki miał wystawić Aleksander (zobowiązanie do pozostania przyszłej żony przy wyznaniu prawosławnym), przywieźli posłowie litewscy z Moskwy do Wilna w lutym 1494 r. (SRIO, T. 35, nr 34, s. 111-137= Daniłowicz, T. 2, nr 2067).

19 LM 5, s. 88. 
z Polską w 1507 roku, wzorując się na retoryce ojca z 1499 roku i lat później$\operatorname{szych}^{20}$ ).

Polscy władcy mieli żony, które z różnych powodów nie zostały koronowane. W czasach ostatnich Piastów i Jagiellonów były dwa takie przypadki. Kazimierz Wielki poślubił mieszczkę praską, Krystynę Rokiczańską, ale nie odważono się jej koronować (małżeństwo morganatyczne). Przeszkodą mogło być przede wszystkim jej mieszczańskie pochodzenie (w mniejszym stopniu to, że nadal żyła w Hesji Adelajda, poprzednia i koronowana żona tego króla, ponieważ przecież za jej życia koronowano następną żonę króla Kazimierza, tj. Jadwigę żagańską, w 1365 roku). Potem już tylko nie koronowano Krystyny, córki Krystiana Ernesta, margrabiego brandenburskiego, żony Augusta II Mocnego, gorliwej luteranki. Używała jednak tytułu regina ${ }^{21}$. Natomiast od czasów Piastów polski władca nie miał żony, która przed ślubem nie porzuciłaby prawosławnego wyznania ${ }^{22}$. Przypomnieć tu można, że Sonka, córka księcia litewskiego Andrzeja Holszańskiego, została najpierw ochrzczona (przyjęła imię Zofia), a dopiero następnie (w 1422 roku) poślubiła króla Władysława Jagiełłę, wreszcie w 1424 roku została koronowana.

Polski i europejski zwyczaj nie pozwalał na koronację osoby prawosławnej. Każdy średniowieczny monarcha europejski sprawował swoje rządy Dei gratia. Z łaski Boga, czyli wprost z Niebios, czerpał swój charyzmat, ale pośrednikiem między władzą świecką a Bogiem był Kościół. W średniowiecznej łacińskiej Europie doby przedreformacyjnej niewyobrażalne było odejście od utrwalonych tradycją rytuałów koronacyjnych, wpisujących się w liturgię mszalną, modlitwy, błogosławieństwo zwierzchnika kościelnego i biskupów oraz namaszczenie. Para królewska otrzymywała monarsze insygnia władzy wyłącznie po uzyskaniu kościelnego błogosławieństwa ${ }^{23}$.

${ }^{20}$ Latopis hustyński pod 1499 r. wymieniał niewybudowanie cerkwi na zamku wileńskim jako główny powód najazdu Moskwy na Litwę, ale autor zaznaczył, że był to pretekst, ponieważ książę moskiewski „chciał ziem litewskich aż po Berezynę” (H. Suszko: Latopis hustyński..., s. 223). Z kolei Wasyl pisał w 1507 r. w liście do Heleny o braku tolerancji religijnej na Litwie (Акты, относящиеся к истории Западной России. Т. 2: 1506-1544. Санктпетербург 1848 (dalej: AZR 2), nr 22, s. 25-26).

${ }^{21}$ H.-J. BötTChER: Christiane Eberhardine. Prinzessin von Brandenburg-Bayreuth, Kurfürstin von Sachsen und Königin von Polen, Gemahlin August des Starken. Dresden 2011.

${ }_{22}$ Brak dowodów, aby prawosławnego wyznania była Aldona-Anna, zaślubiona księciu Kazimierzowi w 1325 r., a następnie koronowana w 1333 r. Zob. J. TęGOwski: Pierwsze pokolenia Giedyminowiczów. Poznań-Wrocław 1999, s. 232-234. Por. też N. DE BaumgarTEN: Généalogies et mariages occidentaux des Rurikides russes du Xe au XIIIe siècle. Roma 1927; TenżE: Généalogies des branches régnantes de Rurikides du XIIIe au XVIe siècle. Roma 1934.

${ }_{23}$ Z. Dalewski: Ceremoniat koronacyjny królów polskich w XV i poczatkach XVI wieku. Kw. Hist. 1995, T. 102, s. 37-60; TenżE: Władza - przestrzeń - ceremoniat. Miejsce $i$ uroczystość inauguracji władcy w Polsce średniowiecznej do końca XIV w. Warszawa 1996, s. $132-189$. 
Helena zaś pozostała prawosławną i nie mogła być koronowana. Monarchia polsko-litewska wobec zagrożenia Wielkiego Księstwa ze strony Moskwy przyjęła wprawdzie stawiane jej warunki, ale w innych łacińskich państwach europejskich podobnej presji nie było. W 1490 roku poseł Iwana III przekazał królowi Niemiec Maksymilianowi I Habsburgowi (cesarzowi rzymskiemu od 1508 roku) odpowiedź na propozycję jego małżeństwa z Heleną. Warunki były dwa: zachowanie przez córkę Iwana wiary prawosławnej i budowa dla niej cerkwi $\mathrm{i}^{24}$. Żądania te zakończyły negocjacje. I kolejna podobna sytuacja: Helena w 1506 roku otrzymała od brata, Wasyla III, wielkiego księcia moskiewskiego, kondolencje w związku ze śmiercią Aleksandra, a wraz z nimi jego prośbę o podjęcie rozmów z „biskupem, panami i całą radą”, by ci przekazali Wasylowi koronę w Polsce i tron wielkoksiążęcy. W zamian deklarował tolerancję religijną. Helena odmówiła, wymawiając się ostatnią wolą męża, który w testamencie wyznaczył brata Zygmunta na swego następcę ${ }^{25}$. Wiedziała, jak nierealny jest to pomysł, podobny do tego, jaki przedstawił jej ojciec w listopadzie 1503 roku, pytając, czy zna córki monarchów Europy Zachodniej, spośród których mógłby wybrać żonę dla swojego syna Wasyla. Otrzymał od Heleny odpowiedź, która musiała być dla niego rozczarowująca. Księżna bowiem wprost napisała, że powinien pytać władców serbskich lub ugorskich (chyba jednak nie węgierskich, ale zakarpackich, a więc może chodziło np. o hospodarów mołdawskich) ${ }^{26}$. Sugerowała zatem ojcu monarchów prawosławnych, a Iwan III budował przecież tożsamość państwową, nieustannie podkreślając równorzędność Moskwy z potęgami europejskimi, jawnie zaś lekceważąc państwa mniejsze i słabsze.

\section{Wychowanie Heleny na dworze moskiewskim}

Zainteresowanie Iwana III mariażami swoich dzieci z władcami europejskimi każe pytać, czy były one przygotowywane do roli, którą miały w przyszłości odegrać. Niewiele jednak wiadomo o wychowaniu i kształceniu dzieci książąt moskiewskich czy choćby „tylko” bojarskich. Nie wiadomo nawet, czy nauka pisania i czytania wchodziła w zakres ich edukacji ${ }^{27}$.

${ }^{24}$ K. Chojnicka: Narodziny..., s. 161-162.

${ }_{25}$ SRIO, T. 35, s. 481-482.

26 Tamże, s. 442-443 = Акты, относящиеся к истории Западной России. Т. 1: 13401506. Санктпетербург 1846 (dalej: AZR 1), s. 318-319.

${ }^{27} \mathrm{Nic}$ na ten temat nie pisze И.Е. ЗАБЕлин: Домашний быт русского народа в XVI и XVII cm. Т. 1: Домашний быт русских иарей в XVI и XVII cm. Москва 1895; Т. 2: Домашний быт русских ияарии в XVI и XVII cm. Москва 1901. 
Poza komnaty zamku kremlowskiego nie wychodziły w zasadzie żadne informacje z życia prywatnego wielkiego księcia oraz jego rodziny, a jeśli już, to niejasne i niesprawdzone pogłoski, zasłyszane przez goszczących w Moskwie dyplomatów czy podróżników ${ }^{28}$. Pierwsze pewne informacje pochodzą dopiero z czasów syna i wnuka Iwana III, czyli Wasyla III (wielkiego księcia moskiewskiego w latach 1505-1533) i Iwana Groźnego (wielkiego księcia od 1533 roku, cara w latach 1547-1584), którzy pokazywali współczesnym kremlowską, imponującą bibliotekę. Iwanowi Groźnemu przypisuje się dodatkowo autorstwo kilku dzieł o charakterze religijnym oraz obszernych listów pisanych w formie traktatów polityczno-religijnych ${ }^{29}$. Jezuita Antonio Possevino, dobrze obeznany z obyczajami panującymi w Wielkim Księstwie Moskiewskim $^{30}$, smętnie odnotował $\mathrm{w}$ raporcie dla papieża Grzegorza XIII, że bawiąc w Moskwie, musiał czytać przez wiele godzin dzieło religijne napisane przez Iwana Groźnego, ale przede wszystkim nadmienił o tym mieście: „Nie ma tam też żadnych szkół średnich ani akademii, lecz tylko szkoły, w których chłopcy uczą się czytania i pisania na Ewangeliach, Dziejach Apostolskich, kronice i na jakichś homiliach, przede wszystkim Jana Chryzostoma" (mowa tu o szkołach cerkiewnych). Powodem stanu powszechnej niewiedzy była, jak pisał dalej Possevino, nie tyle obawa przed herezją, ,ile przede wszystkim niedopuszczenie, by ktoś był od władcy bardziej uczony i mądrzejszy"31. Badacze zgodnie oceniają, że szkoły istniejące $\mathrm{w}$ państwie moskiewskim przy monasterach oraz cerkwiach były w XV i XVI wieku nieliczne, a nauka dzieci duchownych, kupców i rzemieślników odbywała się na niskim, podstawowym

28 A. Possevino (Moscovia. Tłum. A. Warkotsch. Warszawa 1988, s. 46) pisał o pogłoskach, według których Iwan został ciężko pobity przez ojca, gdy stanął w obronie swojej żony, również pobitej przez Iwana Groźnego.

${ }^{29}$ W czasach Wasyla III na Kremlu znajdowała się biblioteka, którą widział uczony mnich Maksym Grek, z „niezliczoną liczbą książek greckich” (o czym pisał anonimowy autor Skazania o Maksymie Filozofie). Kolekcję tę widział potem, już w czasach Iwana Groźnego, luterański pastor jeńców inflanckich Wettermann. Były tam m.in. księgi łacińskie przywiezione z zajętego przez Moskwę Nowogrodu (A.J. DróżDż: Tajemnice księgozbioru Iwana Groźnego. „Annales Academiae Paedagogicae Cracoviensis. Studia Ad Bibliothecarum Scientiam Pertinentia" 2001, T. 1, s. 35-61).

${ }^{30}$ W 1578 r. mianowany został wikariuszem papieskim m.in. na teren Carstwa Rosyjskiego. 27 marca 1581 r. wyruszył z Rzymu w swoją pierwszą misję moskiewską ( 8 kwietnia był już w Bolonii), 2 sierpnia przekroczył granicę polsko-moskiewską z eskortą złożoną z bojarów wydelegowanych z Dumy. W Moskwie bawił do września tego roku. W lutym i marcu $1582 \mathrm{r}$. znów był w tym mieście. W 1585 r. papież wycofał Possevinowi pełnomocnictwo legata. Zob. D. Quirini-Poplawska, Ł. Borkiewicz: Itinerarium ojca Antonia Possevivo SJ (1533-1611). W: Antonio Possevino SJ (1533-1611). Życie i dzieło na tle epoki. Red. D. QuIRINI-PoplaWSKA. Kraków 2012, s. 585-596; A. KiJAs (O. Antonio Possevino SJ o Rosji Iwana IV Groźnego. W: Antonio Possevino SJ..., s. 269) przedstawił nieco odmiennie itinerarium Possevina, niewątpliwie nieściśle.

31 A. Possevino: Moscovia..., s. 14. 
poziomie. Jeszcze zwołany do Moskwy w 1551 roku sobór cerkiewny (znany pod nazwą Stogław = Sto Rozdziałów) wskazywał na częsty wśród duchowieństwa brak umiejętności czytania oraz pisania i postanawiał, aby w Moskwie oraz w innych miastach szkoły powstawały w domach prywatnych i żeby w nich nauczano dzieci ${ }^{32}$.

Helena na pewno była piękną kobietą, co podkreślają źródła ${ }^{33}$, ale o jej osobowości, wychowaniu i wykształceniu wiadomo niewiele. Ojciec przysłał jej

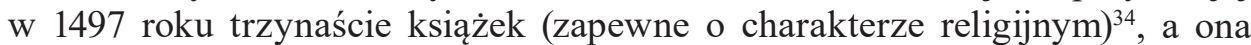
sama miała kupić w Grodnie książki za 25 kóp groszy ${ }^{35}$. Czy je czytała (i czy w ogóle potrafiła czytać) — nie wiadomo. Mogły to być księgi, które — według tradycji - ofiarowywała potem monasterom, np. w Supraślu (o czym dalej). Fryderyk Papée pisał jeszcze o wspólnym zamiłowaniu Heleny i Aleksandra do słuchania muzyki ${ }^{36}$.

Helena wychowała się w licznym gronie swojego rodzeństwa na kobiecym dworze moskiewskim, który to dwór nie był izolowany od świata zewnętrznego. Przeciwnie, wzorując się może na dworach europejskich, dopuszczano księżne (ale chyba nie księżniczki, a przynajmniej nic o tym nie wiemy) do udziału w życiu publicznym, oczywiście za zgodą władcy ${ }^{37}$. Mikołaj von Popplau, składając Iwanowi III w imieniu cesarza propozycję małżeństwa jego córki z margrabią badeńskim, prosił o możliwość jej poznania. Prośba została źle odebrana na Kremlu, usłyszał: ,,...] a tego u nas obyczaju w ziemi nie ma, żeby nam przed sprawą ujawniać swoje córki”38. Posłowie litewscy po

32 Zob. A.J. DRóżDż: Tajemnice księgozbioru..., s. 45: „Wciąż brakuje wielu odpowiedzi na stawiane pytania dotyczące poziomu edukacji w państwie moskiewskim, ale symptomatyczne są nawet pojedyncze fakty, jak ten, że np. akt elekcyjny Borysa Godunowa z 1598 r. podpisało 131 bojarów, a zaledwie 46 postawiło symboliczne krzyżyki — choć tego typu badanie poziomu alfabetyzacji tylko częściowo uzasadnia stawianie hipotez na temat zakresu czytelnictwa".

${ }_{33}$ AZR 2, nr 79, s. 112; Полное собрание русских летописей. Т. 32. Москва 1975, s. 96.

${ }^{34}$ Pisał o tym w liście do córki z 2 listopada tego roku (SRIO, T. 35, nr 49, s. 289).

35 F. PAPÉE: Aleksander Jagiellończyk. Kraków 1949, s. 32.

36 Tamże (z powołaniem na: MRPS, T. 3, nr 2486, 2798, 2847). Zob. też J. SKibNIEwSKA: Dwór królewski Aleksandra Jagiellończyka w latach 1501-1506. Lublin 2015, s. 78-81. K. PietKiewicz (Dwór litewski wielkiego księcia Aleksandra Jagiellończyka 1492-1506. W: Lietuvos valstybé XII—XVIII w. Vilnius 1997, s. 98) wyliczył wynagrodzenia muzyków (na podstawie dwóch ksiąg rachunkowych). Wykazał, że w latach 1498 i 1499 wypłacano kantorom, fletnistom, lutnistom co kwartał od 3 lub 4 do 6 florenów. Wzmianki o muzykach zob. też w: TP. T. 1: Liber quitantiarum Alexandri regis ab a. 1502 ad 1506. Warszawa 1897, s. 52 (1503 r.); Lietuvos didžiojo kunigaikščio Aleksandro Jogailaičio dvaro sąkaitu knygos (1494-1504). Parengè D. Antanavičius, R. Petrauskas. Vilnius 2007, według indeksu (publikacja ksiąg Rachunków Królewskich 23, 25 i 27 z Archiwum Skarbu Koronnego w AGAD).

37 И.Е. ЗАБЕЛИн: Домамний...

38 Opisanie podróży Mikołaja von Popplau, rycerza rodem z Wrocławia. Tłum. P. RADZIKOWSKI. Kraków 1996, s. 158. 
raz pierwszy złożyli pokłon Helenie po zakończeniu negocjacji w sprawie jej małżeństwa z Aleksandrem, tj. 6 stycznia 1495 roku, a więc tuż przed jej wyjazdem z Moskwy do Wilna ${ }^{39}$. Natomiast Zofia, matka Heleny, przyjmowała w Moskwie na życzenie męża dyplomatów, podróżników i posłów, prowadziła z nimi kurtuazyjne rozmowy: wenecki poseł Ambrogio Contarini pisał o długiej rozmowie z Zofią, która przyjęła go łaskawie i uprzejmie ${ }^{40}$; podejmowała kilkakrotnie posłów litewskich negocjujących projekt małżeństwa jej córki $\mathrm{z}$ wielkim księciem litewskim Aleksandrem ${ }^{41}$; był u niej dwukrotnie Jörg von Thurn (Delator), poseł przyszłego cesarza Maksymiliana (latem 1490 i w listopadzie 1492 roku) $)^{42}$. Zofię wymieniają też dwa dokumenty w charakterze rozjemczyni sporu ${ }^{43}$. Można tylko przypuszczać, znając ambicje Iwana III, że

39 SRIO, T. 35, s. 161.

40 Contarini wracał z Persji do Wenecji drogą przez Moskwę, gdzie przebywał od 25 września 1476 do 21 stycznia 1477 r. (А. КонтАрини: Путешествие в Персию. Подгот. текста, пер. и коммент. Е.Ч. СкРжинской. В: Барбаро и Контарини о России: К истории италороссийских связей в $X V$ в. Ленинград 1971, § 28-35, s. 225-231). W polskich wydaniach pominięto jego opis pobytu w Moskwie: Podróż Ambrożego Kontaryniego przez Polskę do Persji 1474-1477. Tłum. J.U. Niemcewicz. W: K. Sienkiewicz: Skarbiec historii polskiej. T. 1. Paryż 1839, s. 1-15; Cudzoziemcy o Polsce. Relacje i opinie. Wybrał i oprac. J. GinTEL. T. 1: Wiek X-XVII. Kraków 1971, s. 104-111.

41 SRIO, T. 35, s. 161.

${ }^{42}$ Wiemy, że 27 stycznia 1494 r. Zofia podejmowała też posłów litewskich negocjujących sprawę poślubienia Heleny przez Aleksandra i wkrótce potem, wraz z mężem, przedstawiła posłom Helenę (tamże, nr 24, s. 117); jeszcze w sierpniu 1494 r. przyjęła posła litewskiego, marszałka hospodarskiego Jana Litawora Chreptowicza — wówczas wręczone zostały podarunki od Aleksandra dla narzeczonej i dla przyszłej teściowej (tamże, nr 28, s. 146); w listopadzie 1494 r. księżnę odwiedził poseł litewski i pisarz wielki litewski Adam Jakubowicz, a na początku 1495 r. kolejni posłowie litewscy (tamże, nr 30, s. 158 i nr 31, s. 161); Jörg von Thurn (Delator), poseł przyszłego cesarza Maksymiliana, odwiedzał Zofię w związku z planami małżeństwa córki Iwana III z Maksymilianem (Памятники дипломатических сношеній древней Россіи съ державами иностранными. Ч. 1: Сношенія съ государствами европейскими. Памятники дипломатических сношеній съ имперіею Римскою. Т. 1: съ 1488 по 1594 годъ. С. Петербургъ 1851, s. 30-35, 82-84).

43 W Moskwie 4 stycznia 1493 r. Wasyl, syn Iwana III, pisał do kniazia Wasyla Michajłowicza Wierejskiego (zm. ok. 1499), syna Michała Andrejewicza Możajskiego (zwanego Wierejskim od dziedzicznej Wierei). Wasyl Wierejski w 1484 r. zbiegł na Litwę, a powodem był spór z Iwanem III o oprawę jego żony, bratanicy Zofii Paleolog, z którą ożenił się w 1480 r. Wasyl Iwanowicz pisał do Wasyla Wierejskiego, że wyjednał u ojca zezwolenie na jego bezpieczny powrót na służbę u Iwana III za wstawiennictwem swojej matki Zofii (Daniłowicz, T. 2, nr 2053). Wierejski wysłał z kolei do Moskwy swojego sługę do jednego z synów bojarskich, aby wstawił się u Wasyla Iwanowicza i jego matki w sprawie przyjęcia go na służbę (Daniłowicz, T. 2, s. 230 przy nr 2053). Z tych zabiegów nic nie wyszło. Kazimierz Jagiellończyk dał Wierejskim jako uposażenie zamek Lubecz nad Dnieprem z włościami. Po śmierci Wasyla Wierejskiego Lubecz został zajęty przez Moskwę w 1503 r. Zob. J. WolfF: Kniaziowie litewsko-ruscy od końca czternastego wieku. Warszawa 1895, s. $549-550$. 
Helena wychowywana była tak, by w przyszłości wkroczyć na arenę europejską bez kompleksów i z nienagannymi manierami dumnej prawosławnej księżniczki, córki potężnego władcy, który odrzucił jako niestosowną propozycję małżeństwa jednej ze swoich córek z ledwie margrabią badeńskim, wskazując, że właściwszy byłby projekt jej małżeństwa z synem cesarza ${ }^{44}$. Podobnie Iwan III nie przyjął oferty nadania mu przez cesarza niemieckiego korony królewskiej (używał wszak tytułu gosudara równoznacznego z tytułem królewskim, ale na dworze cesarskim nie rozumiano, że władcy moskiewscy sami nadawali sobie tytuły, a nie przyjmowali ich od cesarzy czy papieży) ${ }^{45}$.

Późniejsze losy Heleny świadczą, że to poczucie dumy oraz godności osobistej towarzyszyło jej i wówczas, gdy była żoną Aleksandra Jagiellończyka, i potem, już jako wdowie po nim. Musiała odnaleźć się w nowym dla niej polsko-litewskim środowisku, odmiennej kulturze i obyczajowości, a zarazem sprostać trudnym wyzwaniom spowodowanym jej prawosławnym wyznaniem oraz ciągłymi konfliktami zbrojnymi Moskwy z Litwą, którym miała przecież zapobiec. Wiadomo, że posłowie Iwana III wyruszali na dwory europejskie znakomicie poinformowani o sytuacji w poszczególnych państwach czy o ważności osób, z którymi mieli rozmawiać. Można odnieść wrażenie, że wiedza o Polsce i Litwie została Helenie przekazana, ponieważ żaden ze współczesnych polsko-litewskich obserwatorów ówczesnych wydarzeń nie napisał o niej obraźliwie lub krytycznie, choć wcześniej i później nie wahano się ganić polskich królowych, a nawet pisać o nich paszkwili (taki despekt dotknął wszystkich czterech kolejnych żon króla Władysława Jagiełły, później też Bonę Sforzę, żonę Zygmunta Starego, oraz Barbarę Radziwiłłównę, drugą żonę Zygmunta Augusta). Księżna popełniała błędy, ale uczyła się na nich. Dnia 19 sierpnia 1501 roku Aleksander pisał do brata Fryderyka, prosząc o wstawiennictwo u matki, Elżbiety Rakuskiej: „Jeżeli nie spodobały się matce obyczaje i umysł jej [Heleny — G.R.], to ona już odmieniła je na takie, które

${ }^{44}$ W 1489 r. Mikołaj von Popplau przedstawił w imieniu cesarza Iwanowi III projekt małżeństwa Albrechta z córką Iwana (niewątpliwie chodziło o Helenę), co Iwan III krótko skwitował, mówiąc, że jest „z Bożej łaski hospodarem na swojej ziemi i od nikogo ani jego przodkowie, ani on sam nie przyjmie korony" (Opisanie podróży Mikołaja von Popplau..., s. 160; chodziło o Helenę, ponieważ młodsza Fiedosja była wówczas dzieckiem, a starsza Helena już nie żyła, Eudoksja zaś urodziła się ok. 1492 r. - W. Dworzaczek: Genealogia..., tabl. 23). Czy Popplau nie wiedział, że Albrecht zginął w Niderlandach w lipcu 1488 r.? Iwan III wysłał własne poselstwo w 1490 r. do Fryderyka III i dawał do zrozumienia, że jedynym godnym kandydatem do ręki Heleny byłby syn cesarza Maksymilian. Ten projekt Habsburgowie odrzucili, ponieważ Iwan III domagał się gwarancji, że jego córka będzie mogła pozostać przy wyznaniu prawosławnym i zostanie dla niej wybudowana cerkiew w Wiedniu (Памятники дипломатических..., Ч. 1, Т. 1, s. 6, 30, 43, 44 і n.).

${ }^{45}$ Odnotuję jeszcze spostrzeżenie Possevina zawarte w jego relacji dla papieża: „Jeśli chodzi o tytuły królewskie, a nawet cesarskie, to książę nie stara się o nie gdzie indziej, ponieważ sam je sobie przywłaszczył" (A. Possevino: Moscovia..., s. 22). 
będą się jej podobać, a gdyby się nie podobały, to zmieni je zupełnie według woli i rozkazu królowej"46.

\section{Praktyki religijne i fundacje Heleny na rzecz Kościoła wschodniego}

Helena, tak jak inne polskie królowe, żony Jagiellonów, musiała żyć zgodnie $\mathrm{z}$ wizerunkiem dobrej władczyni. Polskie monarchinie odbywały pielgrzymki, uczestniczyły w nabożeństwach, składały ofiary mszalne, udzielały jałmużny biednym, wspierały działalność charytatywną, opiekowały się chorymi i ubogimi etc. Były to $\mathrm{w}$ większości drobne donacje i jedna większa, prestiżowa. Ta główna fundacja dla polskich królowych to kaplice na Wawelu, w których potem były chowane, tam trwała o nich pamięć, modlono się za ich dusze. Takie funkcje spełniały najważniejsze fundacje: królowej Zofii Holszańskiej - kaplica Świętej Trójcy, Elżbiety Rakuskiej — kaplica Świętego Krzyża. Natomiast królowa Bona myślała może o wiecznym spoczynku w kaplicy św. Katarzyny Aleksandryjskiej (zwanej też kaplicą Gamrata (Bona wystawiła biskupowi nagrobek) lub - znacznie później — Grochowskiego), a może nawet planowała swój pochówek w sarkofagu wraz z mężem w kaplicy Zygmuntowskiej. Plany, jakiekolwiek były, stały się nieaktualne wraz z wyjazdem Bony z Polski.

Natomiast Helena konsekwentnie za życia męża i po jego śmierci wspierała Cerkiew prawosławną. Ponieważ nie można było budować nowych cerkwi bez zgody hospodara (ten zakaz złagodzono dopiero w czasach Zygmunta I Starego), pomagała już istniejącym ${ }^{47}$. Dalej wyliczę wszystkie znane mi

${ }^{46}$ Akta Aleksandra króla polskiego, wielkiego księcia litewskiego itd. (1501-1506). Wyd. F. PAPÉE. Kraków 1927, nr 19 oraz nr 25 i 26, gdzie listy Fryderyka do matki z początku września tego roku (w którym wstawiał się za Aleksandrem i jego żoną) oraz do Aleksandra (o tym, że napisał do matki według jego życzenia).

${ }^{47}$ Aleksander tłumaczył m.in. jeszcze w 1495 r. Iwanowi III, że na zamku wileńskim nie można wybudować cerkwi, ponieważ nie pozwalają na to ustawy jego przodków i ojca $($ AZR 1, s. $141=$ LM 5, s. 89 = Daniłowicz, T. 2, nr 2058). W 1503 r. Aleksander w instrukcji dla posłów, mających rozmawiać w Moskwie z Iwanem III, kazał im jednak mówić: „[...] kto w jakiej wierze chce żyć, niech w tej żyje, kto cerkwie jakie chce budować, niech buduje, tak ruskie, jak i rzymskie. Aczkolwiek nie wolno było ruskich cerkwi budować, ale król im na to pozwolił" (AZR 1, s. $348=$ LM 5, s. 195). Sprawa jest niejasna, ponieważ nie jest znany dokument Witolda, Jagiełły, Kazimierza czy Aleksandra z takim postanowieniem. $\mathrm{Na}$ zakaz swoich poprzedników dotyczący budowy nowych czy odnawiania już istniejących 
donacje księżnej, także i te przechowane w tradycji, czasem trudnej do zweryfikowania $^{48}$.

W Wilnie: odnowić miała cerkiew Przeczystej Bogurodzicy (według tradycji ufundowaną przez Juliannę, żonę Olgierda i matkę Jagiełły; w niej też miała zostać pochowana) i monaster Świętej Trójcy ${ }^{49}$. W cerkwi Przeczystej Helena umieściła ikonę Matki Bożej, którą przywiozła z Moskwy na Litwę. W XVII wieku ikonę tę przeniesiono do monasteru Świętej Trójcy ${ }^{50}$. W 1496 roku po-

cerkwi powoływał się jeszcze Zygmunt I dnia 9 września 1510 r. w liście do starosty kamienieckiego, polecając mu stanowczo, by nie zezwalał na budowę cerkwi, zwłaszcza w podległym mu Kamieńcu (Acta Tomiciana. T. 1. Poznań 1852, nr 85). Nowe cerkwie budowano jedynie za zezwoleniem hospodara (już w czasach Zygmunta I: K. CHODYNICKI: Kościół prawosław$n y . .$, s. 79-80). Ograniczenia dotyczące prawosławnych zniósł Zygmunt August w latach 1549 i 1551 (A. Mironowicz: Kościót prawosławny w dziejach dawnej Rzeczypospolitej. Białystok 2001, s. 24, tam pozostała literatura). Trzeba przypomnieć, że Aleksander stosował się do istniejącego zakazu, sformułowanego w prawie kościelnym, czyli w statutach wieluńsko-kaliskich z 1420 r. Od tego zakazu odstąpił dopiero Zygmunt I w drugiej dekadzie XVI w. (K. Chodynicki: Kościót prawosławny..., s. 80-81). Badacze polscy i rosyjscy prezentują często rozbieżne stanowiska w ocenie stosunku Jagiellonów do prawosławia. Nie miejsce tu na omawianie zagadnienia, odsyłam do literatury: Z. Wолткошінк: Dyplomatyka a polityka litewska w końcu XV wieku. „Acta Baltico-Slavica” 1976, T. 9, s. 267-281 (jest to omówienie rozprawy А.Л. Хорошкевич: Жалованые грамоты Литовской метрики кониа XV века и их классификация. В: Источниковедеческие проблемы истории народов Прибалтики. Ред. П. КРАстынь. Рига 1970, s. 47-74). Zob. też przyp. 92.

${ }^{48}$ Prezentowany wykaz to uzupełniona wersja listy opublikowanej przeze mnie wcześniej - G. Rutкowska: Status wdów po królach polskich z dynastii Jagiellonów. W: Kobiety $i$ władza w czasach dawnych. Red. B. CzwojdraK, A.A. KLuczeK. Katowice 2015, s. 254-256.

49 Е. ЦеретелИ: Елена Иоанновна..., s. 273-274.

${ }^{50}$ G. Sosna: Święte miejsca i cudowne ikony. Prawosławne sanktuaria na Białostocczyźnie. Białystok 2001, s. 140-141; A. Troc-Sosna: Gródecka ikona Matki Bożej. „Przegląd Prawosławny” 2002, nr 2 (200). Dostępne w Internecie: http://archiwum.przegladprawoslawny. pl/articles.php?id_n=50\&id=8 [data dostępu: 3.08.2020]; М.Н. БЕРЕжков (Елена Ивановна..., s. 13 i n.) wyliczał dary, które Helena otrzymała od rodziców na drogę. Od ojca dostała bogate ikony, róg okuty srebrem, srebrne naczynia i diadem, a od matki pierścień. Na jednej z ikon podarowanych przez Iwana III, rzeźbionej w macicy perłowej, z klejnotami i złotą koszulką, najprawdopodobniej wyobrażona została sama Helena (umieszczono ją w rogu ikony, ubraną w tradycyjne przybranie głowy, kokosznik, w pozycji klęczącej, modlącą się do wizerunku Matki Bożej z Dzieciątkiem). Innych jej współczesnych portretów nie znamy, a i ten zaginął. Po śmierci Heleny ikona ta znajdowała się w Soborze Przeczystej Bogurodzicy w Wilnie, a w połowie XVII w. przeniesiona została do cerkwi Klasztoru Troickiego (Świętej Trójcy) w Wilnie (gdzie była jeszcze w 1843 r.: „Wizerunki i Roztrząsania Naukowe. Poczet Nowy Drugi” 1843, T. 24 (60), s. 114-116, na s. 118-121 opis ikony). Ponoć Iwan IV ofiarował za tę ikonę Zygmuntowi Augustowi w 1569 r. 50 jeńców litewskich, lecz do wymiany nie doszło (Н. ЕлАгин: Елена Иоанновна, великая княгиня..., s. 83-84). W 1915 r. ikona została wywieziona przez Rosjan i jej los jest nieznany (F. PAPÉE: Aleksander Jagiellończyk..., s. 19). Uzupełnię jeszcze, że Helena, jadąc na początku 1495 r. z Moskwy na Litwę, otrzymała w Smoleńsku w darze ikonę od władyki smoleńskiego (SRIO, T. 35, s. 183). 
darowała wspomnianej cerkwi Przeczystej dobra Żagory ${ }^{51}$. Dnia 12 marca 1510 roku Helena otrzymała od króla Zygmunta I prawo patronatu monasteru funkcjonującego przy cerkwi Świętej Trójcy (w tym czasie był to najważniejszy prawosławny ośrodek zakonny na Litwie, władczyni otrzymała zatem od króla Zygmunta prawo wyznaczania przełożonych monasteru) ${ }^{52}$. Helenie przypisywane jest założenie monasteru Świętego Ducha ${ }^{53}$. Cerkiew Przeczystej Bogurodzicy w Wilnie otrzymała największe wsparcie. Stało się tak być może dlatego, że księżna wybrała ją na miejsce swojego pochówku. Niedaleko, bo w katedrze wileńskiej, pochowany został w 1484 roku Kazimierz (późniejszy święty), brat Aleksandra, i tam też w 1506 roku spoczął jej mąż.

W Bielsku (Podlaskim): tradycja podaje, że Helena ofiarować miała zamkowej cerkwi Narodzenia NMP ikonę Bogurodzicy (ikona ta zachowała się do dziś) $)^{54}$. Ta bielska Hodegetria została prawdopodobnie napisana na wzór wspomnianej ikony przywiezionej przez księżną z Moskwy do Wilna. W 1506 roku król Aleksander polecił staroście bielskiemu przenieść cerkiew zamkową na godne miejsce (cerkiew wybudowano w 1562 roku przy ul. Staromiejskiej) ${ }^{55}$. Tradycja przypisuje Helenie fundację monasteru św. Mikołaja z cerkwią

51 Е. Церетели: Елена Иоанновна..., s. 273, 315; A. Kordiukiewicz: Królowa Helena. „Biuletyn Informacyjny” 2012, nr 2 (56), s. 7. T. NARBUTt (Dzieje narodu litewskiego. T. 8. Wilno 1840, s. 471) podaje, że wspomniane dobra zlokalizowane były w województwie trockim, a królowa nabyła je od Piotra Jacynicza. Wydaje się natomiast, że należy tu odrzucić spotykaną w literaturze identyfikację majątku z Żagorami na Żmudzi, gdzie kościół prawosławny nie miał nigdy dóbr, a rodzina Jacyniczów pojawiła się dopiero w 2. poł. XVI w. (G. BŁAszczy K: Herbarz szlachty żmudzkiej. T. 2. Warszawa 2015, s. 356).

52 AZR 2, nr 58, s. 71. Monaster ten założony został prawdopodobnie w połowie XIV w. (między 1347 a 1350 r.), za sprawą drugiej żony księcia Olgierda, księżniczki twerskiej Julianny (P. Сномıк: Trzej wileńscy męczennicy i początki monasteru św. Trójcy w Wilnie. „Studia Podlaskie" 2011, T. 19, s. 81).

53 Stownik geograficzny Królestwa Polskiego. Т. 13. Warszawa 1893, s. 508; Е. ЦЕРетЕли (Елена Иоанновна..., s. 274) pisze, że Helenie przypisuje się budowę monasteru Świętego Ducha w miejsce drewnianej cerkwi. Podobnie J.I. Kraszewski: Wilno od początków jego do roku 1750. T. 1. Wilno 1838, s. 196 i 387; T. 3. Wilno 1841, s. 49 i 68. Tę tradycję zanegowano, wyznaczając czas budowy na początek XVII w. („Wizerunki i Roztrząsania Naukowe. Poczet Nowy Drugi" 1843, T. 24 [60], s. 114). Budowa cerkwi Świętego Ducha rozpoczęła się w 1596 r. (T. KemPA: Wileńskie bractwo Św. Ducha jako centrum obrony prawosławia w Wielkim Księstwie Litewskim w końcu XVI i w pierwszej połowie XVII w. „Białoruskie Zeszyty Historyczne" 2004, T. 21, s. 47, przyp. 1).

${ }^{54}$ G. Sosna (Święte..., s. 11, 133) przytacza opinię konserwatora zabytków D. Stankiewicza, według którego ikona pochodzi z XVII w. (D. StAnkiewicz: Bielska ikona Bogurodzicy. „Над Бугом и Нарвою. Український часопис Підляшшя” 1994, № 5 (15), s. 20_22). Zob. też G. Sosna: Cudowne ikony na Białostocczyźnie. „Elpis” 1999, T. 1, nr 1, s. 189.

55 A. Kordiukiewicz: Królowa..., s. 7; G. Sosna: Święte..., s. 131. Według Е. ЦЕретели (Елена Иоанновна..., s. 315) być może była to ikona Bożej Matki, którą błogosławili ją rodzice przed wyjazdem z Moskwy. Zob. też A. Radziukiewicz: Bielsk Heleny. Prawosławna królowa. „Przegląd Prawosławny” 2007, nr 7 (265), s. 6-8. 
Zaśnięcia NMP (znajdował się w centralnej części Starego Miasta, w pobliżu Góry Zamkowej) ${ }^{56}$, a także drugiej parafii w tym mieście, czyli św. Michała Archanioła i Objawienia Pańskiego ${ }^{57}$.

W Brańsku (na Podlasiu): władczyni ofiarować miała tamtejszej cerkwi św. Szymona Słupnika ikonę Matki Bożej z Dzieciątkiem (zachowaną do dziś i datowaną obecnie na przełom XVI i XVII wieku) ${ }^{58}$.

W Brasławiu: Helena ufundować miała żeński monaster oraz cerkiew św. Barbary na Górze Zamkowej ${ }^{59}$.

W Grodnie na Kołoży: 20 marca 1500 roku Aleksander Jagiellończyk nadał w obecności księżnej Heleny (dopisek na dokumencie: „Pravila velikaja knehinia”) ihumenowi monasteru św. św. Borysa i Gleba sad na „Kołożaniech”60. Ten monaster powstał przy najstarszej cerkwi w Grodnie. Obecność władczyni może świadczyć o jej wstawiennictwie.

W Kijowie: w literaturze powtarzana jest informacja o „licznych nadaniach", które otrzymał od Heleny monaster św. Mikołaja na Słupie (wymieniany jest rok 1497) ${ }^{61}$. Soborowi Sofijskiemu (Mądrości Bożej) podarować miała, według podań, ikonę, o której wzmiankuje inwentarz soboru z 1697 roku: „[...] чудотврный образ Пресвятыя Боородицы, принесенный в дар польской королевою Еленою в серебряном Позолоченном окладе [...]"62.

56 A. Kordiukiewicz: Królowa..., s. 8; D. MaŁASzewski: Niektóre aspekty życia monastycznego na terenie diecezji włodzimiersko-brzeskiej do końca XVI wieku. W: Życie monastyczne w Rzeczypospolitej. Red. A. Mironowicz, U. Pawluczuk, P. Сномiк. Białystok 2001, s. $110,112-113$.

57 A. Kordiukiewicz: Królowa..., s. 8.

${ }^{58}$ G. Sosna: Święte..., s. 141. Badacz podaje, że konserwatorzy zabytków oceniają czas powstania tej ikony na XVI/XVII w. Zob. też J. TomalskA: Ikona Matki Bożej Hodegetrii z Brańska. Rozważania ikonograficzne. „Biuletyn Konserwatorski Województwa Podlaskiego” 2012, z. 18, s. 37-58; G. SosnA: Cudowne ikony..., s. 190.

${ }^{59}$ K. Jodczyк: Opisy parafii diecezji wileńskiej z 1784 roku. T. 1: Dekanat Brastaw. Białystok 2009, s. 12-13, 36, przyp. h; O. Hedemann: Historia powiatu brasławskiego. Wilno 1930, s. 50 (informuje o hojnej fundacji monasteru), 326 (tu pisze jednak z wahaniem: „[...] widocznie ona założyła też na Górze Zamkowej monaster żeński z cerkwią pod wezwaniem św. Barbary”); Е. ЦЕретели (Елена Иоанновна..., s. 299) podaje, że Helena ufundowała już jako wdowa żeński monaster. Z kolei A. KordiukiewiCz (Królowa..., s. 8) pisze, że wybudowała cerkiew i założyła żeński klasztor.

${ }^{60}$ Kronika ihumenów, archimandrytów, fundatorów i protektorów monasteru grodzieńskiego nа Kołoży w: Археографический сборник документов, относящчихся к истории СевероЗападной Руси. Акты Виленской Комиссии для разбора древних актов. Т. 9. Вильна 1870, s. 416. Zob. też J. JoDKowski: Świątynia warowna na Kołoży w Grodnie w świetle badań archiwalnych $i$ archeologicznych dokonanych $w 1935$ r. Grodno 1936, s. 7-8, 55, przyp. 1.

${ }^{61}$ A. Kordiukiewicz: Królowa..., s. 7; A. Mironowicz: Helena Iwanowna fundatorka cudownej bielskiej ikony Matki Bożej. W: Wszechnica Kultury Prawosławnej. T. 6. Red. A. Kuźma, J. Sмyк. Białystok 2009, s. 25.

62 Cytat za: A. Сапунов: Древние иконы Богоматери в Полоияой епархии. Витебск 1888, s. 14; zob. też И.А. ШАЛинА: Икона Богоматери Одигитрии - древняя икона 
Jest to jedyny przekaz na ten temat. Może Helena uczyniła to podczas pobytu wraz z mężem w Połocku? (Była tu w kwietniu 1497 oraz w 1500 roku) ${ }^{63}$. Na przełomie XVII i XVIII wieku ikona zaginęła (zabrana została przez komendanta wojsk carskich Ozerova i przewieziona do Smoleńska; jej dalszy los jest nieznany) ${ }^{64}$.

W Mińsku: Helenie przypisuje się budowę monasteru i rozbudowę cerkwi Wozniesieńskiej (Wniebowstąpienia Pańskiego) ${ }^{65}$, której zapisała własne dobra oprawne koło Mińska, czyli Trościeniec (crinile donatio propter nuptias), a nadanie to zatwierdził król Aleksander w 1502 roku $^{66}$. Wzmianka o ufundowaniu przez księżną monasteru w Mińsku znajduje się też w Kronice ławry supraskiej (spisanej w XVIII wieku) pod 1516 rokiem $^{67}$.

W Supraślu: tradycja przypisuje Helenie opiekę nad tutejszym monasterem. Tradycja ta opiera się na kilku informacjach. W Субботнике или Поминнике supraskim (kopia z 1631 roku) księżna wymieniona została wśród dobrodziejów klasztoru, za dusze których modlono się ${ }^{68}$ (spisywanie pomianików było obowiązkiem każdego monasteru — od chwili jego założenia). Z kolei w rejestrze wydatków na wyposażenie monasteru i posiadanych przez niego rzeczy, w tym ksiąg, wpisano informację, że Helena ofiarowała klasztorowi Księge Asafa z życiem św. Sergiusza Cudotwórcy ruskiego i Ksiegge Asafa z chożdzieniem Daniła ${ }^{69}$. W przywileju Zygmunta Augusta z 3 kwietnia 1545 roku,

Полоикого Софийского собора. В: Сборник статей: K 60-летию со дня рождения Валентина Александровича Булкина. Санкт-Петерург 1999, s. 125-126.

${ }_{63}$ Zob. G. RutKowska: Podróże polskich królowych z XV wieku. W: Samotrzéc, w kompanii czy z orszakiem? Społeczne aspekty podróżowania w średniowieczu i czasach nowożytnych. Red. M. SaCzyńska, E. WóŁkiewicz. Warszawa 2012, s. 189-190; K. Pietkiewicz: Itinerarium króla Aleksandra Jagiellończyka 1492-1506. Warszawa 2016, s. 62 i 81.

${ }^{64}$ И.А. ШАлинА: Икона Богоматери Одигитрии..., s. 127.

${ }^{65}$ Е. Церетели: Елена Иоанновна..., s. 275.

${ }^{66}$ Zbiór dawnych dyplomatow i aktow miast mińskiej gubernii, prawosławnych monasterów, cerkwi $i$ w różnych sprawach. Mińsk 1848, nr 57 (Zygmunt III w 1616 r. potwierdził dokument Aleksandra, który z kolei potwierdził nadanie przez „królową” Helenę majętności Trościeniec monasterowi Wozniesieńskiemu w Mińsku; Stownik geograficzny Królestwa Polskiego. T. 6. Warszawa 1885, s. 459; Е. Церетели: Елена Иоанновна..., s. 275).

${ }^{67}$ Kronika tawry supraskiej w: Археографический сборник документов..., s. 37: „[...] Heleny, od której ten monaster miński fundowany”.

${ }_{68}$ Субботник или Поминник С[упрасльсаго] монастыря. В: Археографический сборник документов..., s. 456; П. Гильтеьрандт: Рукописное отделение Виленской публичной библиотеки, вып. 1: I - Церковно-славянские рукописи, II - Русские пергамены. Вильна 1871, с. 15-20, nr 14 (s. 17 i przyp. 2: królowa Helena).

${ }^{69}$ Ostatnio przypisano Helenie podarowanie monasterowi supraskiemu także dwóch żywotów Barlaama i Joasafa oraz jednego pateryku (Rękopisy supraskie w zbiorach krajowych i obcych: katalog rękopisów supraskich. Oprac. A. Mironowicz [i in.]. Białystok 2014, s. 66, katalog nr 24), ale jak podkreślał w recenzji A. Siemaszko (O historii monasteru supraskiego i jego bibliotece: uwagi do ksiązki: Rękopisy supraskie w zbiorach krajowych i obcych: katalog rękopisów supraskich, oprac. Antoni Mironowicz et al. wyd. Libra, Biatystok 2014, ss. 392. 
w którym zatwierdził granice i nadania dla monasteru supraskiego oraz prawa nadane przez Aleksandra Jagiellończyka i Zygmunta Starego, wspomniano ogólnie (bez daty), że klasztor otrzymał nadania także od królowej Heleny ${ }^{70}$.

Tylko na tradycji opiera się opinia o przekazaniu przez Helenę monasterowi ikony Matki Bożej Włodzimierskiej, czyli Matki Bożej z Dzieciątkiem, przedstawiającej scenę Umilenia ${ }^{71}$. Nadto metropolita kijowski (litewski) Jonasz III Rusin otrzymał od Heleny krzyż z cząstką Krzyża Świętego, który dostała ona w 1503 roku od swej matki Zofii. Krzyż miał przekazać do Supraśla metropolita kijowski Józef Sołtan w 1507 roku. Aleksander Siemaszko podkreśla, że nie wiadomo, czy krzyż supraski i krzyż przekazany Helenie przez matkę są tożsame ${ }^{72}$.

Przedstawione donacje rozłożone były w czasie. Natomiast na co dzień Helena uczestniczyła w nabożeństwach i modlitwach w obrządku wschodnim.

Księżna wyjechała z Moskwy 13 stycznia 1495 roku, a następnego dnia, na pierwszym postoju pod Moskwą, w pobliskim Dorogomiłowie, Iwan III dał córce na piśmie ostatnie zalecenia dotyczące jej życia religijnego: ,[...] do ła-

„Studia Podlaskie” 2014, T. 22, s. 223 i 237), nie ma tam żadnych zapisów, które sugerowałyby, że były to dary Heleny.

${ }^{70}$ Prawa i przywileje miasta i dóbr ziemskich Zabłudów XV-XVIII w. Oprac. J. MaroSZEK. Białystok 1994, s. 42, punkt 4. Wydawca podaje, że dokument Zygmunta Augusta znany jest z oblaty w księdze sądu zamkowego zabłudowskiego z lat 1717-1747 (księga przechowywana jest w Centralnym Historycznym Archiwum Białorusi w Mińsku, F. 1716, op. 1, nr 1, k. 251-253). Wydawca napisał też: „Widocznie w 1509 r. Helena wystawiła akt aprobujący fundację, gdy przyłączyła do Bielska skonfiskowaną Aleksandrowi Chodkiewiczowi Puszczę Supraską (Błudowską)" (s. 42).

71 A. Siemaszko: O historii monasteru..., s. 210. Por. G. Sosna: Święte..., s. 313; A. KorDIUKIEwICZ: Królowa..., s. 7; H. SuRYNowicz: Życie monastyczne na Grodzieńszczyźnie w XIX wieku. W: Życie monastyczne..., s. 225. Helena posiadała od 5 stycznia 1507 r. jako dożywotnie zabezpieczenie wdowie Bielsk, Suraż i Brańsk (Lietuvos Metrika. Knyga Nr. 8 (1499-1514). Užrašymu knyga 8. Vilnius 1995, nr 180, s. 187-188). Ikonę ofiarować miała władyce smoleńskiemu i metropolicie kijowskiemu Józefowi Sołtanowi, a ten przekazał ją klasztorowi w Supraślu. Obraz namalowany był na płótnie i naklejony na deskę, na odwrociu znajdował się napis w języku polskim, stwierdzający, że ofiarowany został przez Helenę, za pośrednictwem Józefa Sołtana (ikona do 1915 r. była w Supraślu, uznawana jest za zaginioną; fotografia wykonana przez Józefa Jodkowskiego w 1910 r., przechowywana w Instytucie Historii Sztuki PAN, Fototeka nr 9429; publikowana m.in. w: J. MAroszeK: Pogranicze Litwy i Korony w planach króla Zygmunta Augusta. Z historii dziejów realizacji myśli monarszej między Niemnem a Narwiq. Białystok 2000, s. 10).

72 Zob. Е. Церетели: Елена Иоанновна..., s. 242. Autorka opiera się tu niewątpliwie na relacji zawartej w moskiewskiej księdze poselskiej: posłowie moskiewscy przywieźli do Wilna wieść o śmierci matki Heleny, przekazali jej ostatnie błogosławieństwo oraz złoty krzyż z cząstkami Krzyża Świętego i relikwiami, który Zofia Paleolog poleciła oddać córce (SRIO, T. 35, s. 415). A. SiemaszKo (O historii monasteru..., s. 201-203) nie wyklucza, że „ofiarowanie krzyża [klasztorowi supraskiemu przez metropolitę Jonasza III Rusina — G.R.] mogło nastąpić w momencie poświęcenia cerkwi (jej założenia?) w 1503, o czym pisze Pomianik z 1631 r." (tamże, s. 202). 
cińskich kościołów ma nie chodzić, a do swojej cerkwi, a jeśli zechce zobaczyć łacińskie świątynie lub klasztory, to tylko raz lub dwa, ale nie więcej, a kiedy królowa, matka Aleksandra, będzie we Wilnie, może ją odprowadzić do kościoła, a potem pójść do swojej cerkwi" "’3.

W literaturze zwykle opisuje się zaślubiny Heleny i Aleksandra następująco: ona udała się najpierw do cerkwi, a Aleksander — do katedry. Potem Helena przejechała $\mathrm{w}$ uroczystym orszaku do katedry. Na jego czele znajdował się przybyły na tę okoliczność z Moskwy pop Tomasz (po rusku Foma), $\mathrm{z}$ krzyżem prawosławnym $\mathrm{w}$ dłoni. $\mathrm{Z}$ katedry na spotkanie władczyni wyszedł biskup wileński Wojciech Tabor - trzymał on krzyż rzymski, ale nie pobłogosławił nim Heleny ${ }^{74}$. W katedrze do ceremonii włączono elementy obrządku wschodniego: nad głową Heleny trzymano ślubną koronę (wieniec), a pop asystował w ceremonii, ale „nawet nie śmiał głośno czytać modlitw po rusku”75.

Temat ten pogłębię, ponieważ źródła na to pozwalają. Trzeba podkreślić, że dotyczące przebiegu ceremonii ślubnej warunki stawiane przez Iwana III nie wynikały $\mathrm{z}$ jego własnych przemyśleń czy uporu. To były żądania zgodne z normami kanonicznymi obowiązującymi w Kościele wschodnim i tylko ich dopełnienie gwarantowało ważność małżeństwa. Między Kościołami Wschodu i Zachodu już od IV wieku narastały odmienności zarówno w odniesieniu do teologii małżeństwa, jak i w liturgii sakramentu ślubu. Różnice dotyczyły przede wszystkim obrzędu błogosławieństwa udzielanego nowożeńcom przez kapłana. Na ten ryt liturgiczny składały się modlitwy i hymny. Od V wieku ritus sacer, połączony z ofiarą eucharystyczną, stał się warunkiem ważności zawieranego małżeństwa i potwierdzany był przez kolejne sobory czy synody Kościołów wschodnich. Forma kanoniczna obowiązująca nowożeńców prawosławnych obejmowała: wyrażenie zgody na ślub, aktywny udział kapłana szafarza tego sakramentu, obecność co najmniej dwóch świadków i obrzęd polegający na udzieleniu błogosławieństwa nowożeńcom przez duchownego. Wyrażenie zgody oznaczało, że oboje musieli być obecni w miejscu celebracji. Kapłan zaś musiał mieć upoważnienie do błogosławienia małżeństwa od hierarchy miejsca. On nie tylko przewodniczył uroczystości liturgicznej zaślubin i błogosławił małżeństwo, ale w tradycji wschodniej był rzeczywistym reprezentantem Boga, prawdziwym szafarzem działającym mocą Ducha Świętego zgodnie ze wschodnim ujęciem tego tematu. Kapłan ów przyjmował od małżonków przysięgę i udzielał im błogosławieństwa ${ }^{76}$. W przypadku Heleny i Aleksandra, należących do dwóch Kościołów, w celebrze - według przeka-

${ }^{73}$ SRIO, T. 35, s. 163.

${ }_{74}$ Полное собрание русских летописей. Т. 24. Петроградъ 1921, s. 240.

75 „Древняя российская вивлиофика” 1790, Т. 14, s. 11-12.

${ }^{76}$ R. Holubowicz: Kanoniczna forma zawarcia malżeństwa w świetle Kodeksu Kanonów Kościołów Wschodnich. „Ius Matrimoniale. Ze studiów nad kościelnym prawem małżeńskim” 2013, T. 18 (24), s. $123-150$. 
zów źródłowych — uczestniczyli duchowni obu wyznań. Jeszcze 12 stycznia 1495 roku Iwan III pytał obecnych w Moskwie posłów Aleksandra, kto udzielać będzie ślubu. Odpowiedzieli, że Aleksandrowi biskup, a Helenie metropolita, a jeśli będzie nieobecny — wówczas władyka. Sprawa chyba nie była do końca uzgodniona z Aleksandrem, ponieważ posłowie natychmiast wysłali do niego list ${ }^{77}$. Jeszcze w czasie przejazdu Heleny z Moskwy do Wilna, w lutym 1495 roku, bojarzy pytali panów litewskich, czy ślub odbędzie się w cerkwi i czy udzieli go metropolita lub władyka albo archimandryta wileńskiego monasteru Świętej Trójcy Makary (sprawujący zarazem pieczę nad wszystkimi monasterami na terenie Litwy, wybrany w 1494 roku metropolitą kijowskim). Poseł Aleksandra dotarł do postoju orszaku Heleny w Miednikach i tam bojarzy usłyszeli, że ślub odbędzie się w łacińskim kościele ${ }^{78}$.

„Ślub dawał w kościele ś. Stanisława w Wilnie Aleksandrowi biskup miejscowy rzymski. Wielkiej księżnie zaś Helenie, w tymże kościele, ślub dał według greckiego obrządku pop wielkiego księcia moskiewskiego Tomasz [...]. Dla kierowania sprawami ślubu i zawiezienia darów wysłany był diak Wasilij Żukow"79.

Pop Tomasz (Foma), wyznaczony przez Iwana III na opiekuna duchowego Heleny, został przez nią z nieznanych powodów i wbrew protestom wielkiego księcia moskiewskiego odesłany do Moskwy w 1497 roku, a swoje sprawy duchowe księżna powierzyła miejscowemu popowi. Nie znamy jego imienia, wiadomo tylko, że — jak pisała Helena do Iwana III — cieszył się w Wilnie dobrą opinią ${ }^{80}$. Ona sama zapewniała ojca kilkakrotnie, że nie ma trudności w spełnianiu obowiązków religijnych. Przykładowo, 2 stycznia 1503 roku (indykcja 6) pisała do niego z Wilna (relacjonowała niewątpliwie swój pobyt w Polsce w 1. poł. 1502 roku), że ma pełną swobodę wyznawania wiary, zarówno na Litwie, jak i w Polsce, „mianowicie w Krakowie i po wszystkich miastach polskich”. Podkreślała, że ,po cerkwiach świętych chodzi”, a na jej dworze są ,świaszczenniki [duchowni — G.R.], popi, diakoni i piewcy”. Od męża zaś otrzymała miłość, a od poddanych „dary i służbę”. Miała jednak przynieść Litwie pokój, a z powodu wojen — pisała — ,jak mam oczy swoje pokazać świekrze swojej?" ${ }^{81}$. Zbliżone w treści listy wysłała tego dnia też do swojej matki,

77 SRIO, T. 35, s. 162.

78 Tamże, s. 184, 185.

79 Daniłowicz, T. 2, nr 2083.

${ }^{80}$ M.Н. Бережков: Елена Ивановна..., s. 22. A. Winiarska (Rola..., s. 13-14) przypuszczała, że może był to późniejszy archimandryta monasteru Wniebowstąpienia Pańskiego (Wozniesieński) w Mińsku i późniejszy metropolita kijowski Jonasz II Rusin.

${ }^{81}$ Акты, собранные в библиотеках и архивах Российской империи Археографической экспедицией. Т. 1: 1294-1598. Санктпетербургъ 1838, nr 138 [I-II], s. 104-107 = T. NARвUтт: Dzieje narodu..., dodatek V, s. 19-25; tłum. na język polski = Daniłowicz, T. 2, nr 2151. Także w jednym z latopisów pod 1501 r. pojawiła się wiadomość o tym, że Helena miała na zamku krakowskim „cerkiew”, w której odprawiano dla niej nabożeństwa (Kroniki Bernarda 
do braci Wasyla i Jerzego ${ }^{82}$. Podobnie w liście z marca lub kwietnia 1503 roku informowała ojca, że mąż „przez wszystkie te lata i obecnie [...] w niczym nie uchybia wcześniejszej łaskawości i szczodrobliwości, dobrowolnie pozwala mi wyznawać wiarę chrześcijańską w obrządku greckim"»3.

Do Iwana docierały zaś całkiem inne opinie. Dnia 30 maja 1499 roku kniaź Borys Michajłowicz Oboleński donosił księciu moskiewskiemu, że otrzymał list od niejakiego Fedki Szestakowa (prawdopodobnie z otoczenia Heleny), w którym ten pisał mu, że Aleksander „niewolił” Helenę, nakłaniając ją do wiary łacińskiej, i to samo czyni wobec prawosławnych na Litwie ${ }^{84}$. Te wieści potwierdzał potem książę Siemion Bielski, oddając się pod władzę Iwana III i informując go o wizycie u Heleny, przysłanych przez jej męża, metropolity kijowskiego Józefa I Rusina oraz biskupa wileńskiego i przedstawicieli bernardynów wileńskich ${ }^{85}$. Może nie znał różnic w poglądach między nimi, a może ich nie rozumiał. Mówił zaś o „wielkim przymuszaniu” wyznawców prawosławia do zmiany wiary. Podobnie twierdzili kolejni uciekinierzy z Litwy. Takie też opinie przeniknęły do latopisów (np. sofijskiego pierwszego) ${ }^{86}$. Oczywiście, podczas rozmów pokojowych toczonych w Moskwie w 1503 roku polscy i litewscy posłowie zapewniali, że o żadnym „przymuszaniu” do zmiany

Wapowskiego z Radochoniec kantora katedr. krakowskiego. Część ostatnia, czasy podtugoszowe obejmujaca 1480 - 1535. Wyd. J. SzUjSk. W: Scriptores rerum Polonicarum..., s. 308 wydawca zacytował Latopis hustyński; zob. H. Suszko: Latopis hustyński..., s. 73 i 224 (przekład), z powołaniem na pracę: Historia Kościoła w Polsce. T. 1. Cz. 1. Red. B. Kumor. Poznań 1974, s. 356). Marcin Bielski też podawał, że Helena miała na zamku wawelskim własną kaplicę (Kronika polska Marcina Bielskiego. Kraków 1597, s. 494). Napisał również, że na dźwięk organów uciekła z kościoła, zowiąc je dudami (M. BIELSKI: Kronika wszystkiego świata. Kraków 1551, k. 258v). Ucieczkę ze świątyni spowodowała pewnie nie głośna gra instrumentu, lecz zakaz ojca, który otrzymała na piśmie w dniu wyjazdu z Moskwy do Wilna 13 stycznia: ,[...] aby nie chodziła do kościoła łacińskiego, chyba raz lub dwa może obejrzeć kościół i klasztory łacińskie" (SRIO, T. 35, s. 163). Iwan III powtórzył zakaz w 1503 r.: ,[...] zaklinam cię córko, abyś [...] do kościołów nie chodziła [...], proś męża, aby ci [...] cerkiew wystawił, dał do usług panie greckiego obrządku, a sługi łacińskie od ciebie oddalił”, i dalej: „Jeśli córko wiarę odmienisz, nie tylko od Boga zostaniesz odrzuconą, ale nie otrzymasz miłości i błogosławieństwa mego ani twej matki, z zięciem zaś naszym o to wieczną prowadzić będziemy wojnę" (Акты, собранные в библиотеках..., T. 1, nr 138 [V], s. 109-110 = Daniłowicz, T. 2, nr 2154).

82 T. Narbutt: Dzieje narodu..., dodatek V, s. 25-30.

${ }^{83}$ SRIO, T. 35 , s. 369.

${ }^{84}$ Tamże, s. 273-274. Iwan III zareagował natychmiast, wysłał do Heleny bojara Iwana Grigoriejwicza Mamonowa, przekazując jej dwie gramoty, od niego i matki Zofii. Pytali, czy wieści są prawdziwe i żądali pozostania przy wierze greckiej (tamże, s. 274-276).

${ }^{85}$ Полное собрание русских летописей. Т. 8. Санктпетербургъ 1859, s. 238; Полное собрание русских летописей. Т. 5. Санктпетербургъ 1851, s. 45.

${ }^{86}$ Pod 1495 r. informacja o zmuszaniu Heleny do wiary rzymskiej przez Aleksandra: Полное собрание русских летописей..., Т. 6, s. 39 = Scriptores rerum Polonicarum..., s. 311. 
wiary Heleny i litewskich poddanych nie ma mowy, a chodzi tylko o uznanie prymatu papieża, ponieważ bez tego księżna nie może być koronowana. Porozumienia nie osiągnięto ani wówczas, ani w przyszłości. Helena nigdy nie zgodziła się na kompromis proponowany przez bernardynów, powołanych do krzewienia wiary na Wschodzie, by uznała prymat papieski z zachowaniem obrzędów greckich. Może zadziałała tu groźba rzucenia na nią klątwy rodzicielskiej, zawarta w kolejnych listach otrzymywanych od ojca i matki w roku 1499 i $1503^{87}$.

Nie ulega wątpliwości, że Helena mogła w Polsce czy na Litwie swobodnie oddawać się praktykom religijnym w obrządku prawosławnym. Umożliwiał je antymins, czyli niezbędny element wyposażenia stołu ofiarnego (wspominany w źródłach od końca VIII lub początku IX wieku; pierwsze zachowane pochodzą z XII wieku). Był przenośnym ołtarzem i zastępował poświęcenie cerkwi przez biskupa, pozwalał sprawować Świętą Liturgię i Eucharystię także w cerekwicach, czyli kaplicach lub w domowych cerkwiach. Stare ruskie antyminsy sporządzano aż do XVII wieku ręcznie na tkaninie lnianej, tuszem rysowano wyobrażenie krzyża Golgoty. Antymins przekazywał kapłanowi zawsze biskup i był to widomy znak, że kapłan jest upoważniony do sprawowania Świętej Liturgii, znak jego podporządkowania się jurysdykcji biskupa, który antymins poświęcił, namaścił świętym Mirem (Krzyżmem) i umieścił w nim cząstki relikwii świętych męczenników na zewnętrznej stronie w zaszytej zakładce (a więc nadał mu moc kanoniczna), na koniec zaś podpisywał, wpisując datę, swoje imię i tytuł ${ }^{88}$. Antymins przypominał zatem Helenie, że modli się, najpewniej codziennie, przed świętym ołtarzem w trwałej i nierozerwalnej więzi z Cerkwią prawosławną oraz jej biskupem, ze świętymi tego Kościoła i jego wyznawcami. Antymins rozkładany mógł być w każdym miejscu, także w podróży lub w domowej cerkwi — źródła wspominają taki domowy kościół urządzony dla Heleny na zamku krakowskim (kronika Bielskiego, a za nią Latopis hustyński z początku XVII wieku) ${ }^{89}$. Antymins był odpowiednikiem

871499 r.: SRIO, T. 35, s. 275, 276, 278-280; 1503 r.: T. NARBUtT: Dzieje narodu..., dodatek V, s. 30-31: Iwan III w odpowiedzi na list Heleny z 2 stycznia [1503 r.], w którym zapewniała go, że ma pełną swobodę wyznawania wiary, pisał, iż wiadomo mu, że byli u niej władyka smoleński, biskup wileński oraz tamtejsi bernardyni i namawiali ją, by przystąpiła do wiary rzymskiej. Nakazywał więc Helenie, by trwała w swojej wierze, nie chodziła do kościołów rzymskich i prosiła męża o wybudowanie dla niej cerkwi oraz by pozwolił jej mieć przy sobie „panów i panie greckiego wyznania”.

${ }_{88}$ M. Filimoniuk: Historia antiminsa a Boska Liturgia. „Wiadomości Diecezji Białostocko-Gdańskiej” 2005, nr 21 (55), s. 10-14; H. PAProcki: Antimension (gr. antiminsion, stow. antimins). W: Encyklopedia katolicka. T. 1. Red. F. GrYGolewicz [i in.]. Lublin 1985, kol. $643-644$.

${ }^{89}$ H. Suszko: Latopis hustyński..., s. 224: ,[...] miała dla siebie cerkiew na zamku krakowskim, w niej zaś wedle obyczaju ruskiego nabożeństwa jej odprawiali”; M. BIELSKı: Kronika polska..., s. 494. 
ołtarza przenośnego (altare portatile) wyznawców obrządku łacińskiego, którego używano na podstawie indultu papieskiego.

Ciekawe i współczesne wydarzeniom świadectwo znalazło się w kronice Jana z Komorowa. Pod 1494 rokiem pisał on, że „Jeden biskup w Wilnie zakazał pewnemu wiernemu obrządku greckiego, mającemu wspólnotę z Rzymem, odprawiania mszy świętej w swoim rycie, chociaż w Krakowie mógł je spokojnie odprawiać”, a dalej, że ów biskup „obawiając się wezwania do Kurii Rzymskiej i upomnienia przez papieża z powodu krzywdy wyrządzonej temu kapłanowi, skierował do papieża pismo wyjaśniające" ${ }^{90}$. Czy Helena uczęszczała do świątyni, w której msze w rycie greckim sprawowali ci, którzy uznali prymat papieski? Zapewne nie.

Funkcjonowanie cerkwi w XV i XVI wieku dobrze poświadczone jest na Podlasiu - w Bielsku, a więc w dobrach oprawnych Heleny — tę ,cerkiew Rusinów, poza zamkiem” wspomniał Jan z Komorowa, opisując poufne spotkanie Heleny z wysłannikami Iwana III w sprawie jej wyjazdu wraz z dworem i zgromadzonymi przez nią skarbami do Moskwy ${ }^{91}$.

Nie wybudowano natomiast dla Heleny, wbrew żądaniom Iwana III, cerkwi na zamku w Wilnie. Już w 1494 roku Aleksander tłumaczył księciu, że nie jest to możliwe, i powoływał się na „od dawna obowiązujące prawo" ${ }^{2}$. Helena mogła jednak uczęszczać do kilku świątyń znajdujących się w Wilnie. Tylko w północno-zachodniej części tego miasta, między Ostrą Bramą a kościołem Franciszkanów, były trzy: Troicka z kościołem Bazylianów, naprzeciw - cerkiew Świętego Ducha z monasterem, a nieco niżej, nad Wilejką i przy bramie Spaskiej, cerkiew soborowa metropolitalna pw. Wniebowzięcia NMP, czyli zwana po rusku: Przeczystej Bogurodzicy. W Wilnie księżna powinna czuć się dobrze ze względu na mieszany narodowościowo i wyznaniowo charakter tego miasta, ponieważ — jak pisał ks. Jan Fijałek — „Ruska to była jeszcze

90 JAN Z Komorowa: Kronika Zakonu Braci Mniejszych Obserwantów (1209-1536). Tłum. K. ŻUchowski. Kalwaria Zebrzydowska 2014, s. 259.

${ }_{91}$ Tamże, s. 306.

${ }_{92}$ Ten zakaz nie był jednak oparty na dokumencie królewskim, ponieważ jego istnienia nie potwierdza żadne źródło. W dawniejszej literaturze przypisywano Kazimierzowi, synowi króla Kazimierza Jagiellończyka, wyjednanie u ojca wydania tego zakazu, ale pogląd ten obalił J. Fijałek. Zob. Kopiarz rzymski Erazma Ciołka z pocz. wieku XVI-go. Oprac. S. KutrzeBA, J. FiJAlek. AKH 1923, Seria 2, T. 1, s. 66; J. FiJAlek: Opisy Wilna aż do polowy wieku XVII-go [cz. 1]. „Ateneum Wileńskie” 1923, R. 1, nr 3-4, s. 131. Z kolei do zakazu księcia Witolda odwoływały się uchwały synodu prowincjonalnego łęczyckiego z 1527 r. i synodu diecezji wileńskiej z lat 1527 i 1528, ale i tego dokumentu nikt nie odnalazł (TenżE: Opisy Wilna aż do połowy wieku XVII-go [cz. 2]. „Ateneum Wileńskie” 1924, R. 2, nr 5-6, s. 155, przyp. 1; Tenże: Pierwszy synod diecezji wileńskiej w katedrze św. Stanisława 1520/21. „Kwartalnik Teologiczny Wileński” 1923-1924, R. 1-2, s. 81; J. SAwicki: Concilia Poloniae. Źródta i studia krytyczne. T. 3. Warszawa 1948, s. 13). Dokument Aleksandra Jagiellończyka: AZR 1, nr 116, s. 141 = Daniłowicz, T. 2, s. 241. Zob. też przyp. 47. 
dzielnica od Ostrej Bramy ku Wilence aż do bramy Spaskiej wraz z ich przedmieściami, przepełniona małymi cerkiewkami (kaplicami)"93.

Trudno powiedzieć, jak Helena odebrała wydarzenia z wiosny 1495 roku, gdy na polecenie Aleksandra odesłano do Moskwy większość jej kilkudziesięcioosobowego orszaku przybyłego wraz z nią z tego miasta (niewątpliwie powodem były trudne do ukrycia zadania wywiadowcze wykonywane na rzecz jej ojca $)^{94}$. Przy księżnej pozostało nieliczne grono jej prawosławnych dworzan i dwórek, była wśród nich też — jak pisał Jan z Komorowa — „Pewna pani, księżna prawosławna, lecz wierna ochmistrzyni, którą królowa lekceważyła"95. Być może wytłumaczono Helenie, że w Polsce zawsze odsyła się do kraju rodzinnego większość dworzan i dwórek przybyłych z przyszłą żoną władcy.

93 J. FiJaleK: Opisy Wilna..., [cz. 1], s. 333-334.

94 J. Garbacik (Helena..., s. 360) pisze, że z Heleną do Wilna przybyło ok. 80 osób. Według dokumentu opublikowanego przez Daniłowicza byli to posłowie Iwana III, tj. książę Siemion Iwanowicz Riapołowski z żoną Marią, Michał Jakowlewicz Rusałka z żoną oraz diak Wasyl Kuszenin. Wraz z księżną przyjechał dworzanin Iwana III, czyli Dymitr Pieszkow, syn Siemiona, ze swoją świtą, nadto wielu innych książąt, bojarów z żonami i dziećmi, dworzan. Po ślubie Aleksander odesłał do Moskwy posłów Iwana III, a przy Helenie pozostali: książęta Wasyli Wasyliewicz Romodanowski i Aleksander Juriewicz, dalej Jan Bereziński, Prokofij Skuratow i Dymitr Pieszkow (Daniłowicz, T. 2, nr 2083, z powołaniem na dokument wydany w: „Древняя россійская вивліоөика” 1790, Т. 14, s. 1; por. LM 5, s. 90; zob. też: K. РіЕTKIEwICz: Dwór litewski..., s. 94-95). Przy królowej pozostawiono najwyżej kilka dwórek przywiezionych przez nią z jej domu rodzinnego. Tylko przykładowo: przy Jadwidze Andegaweńskiej były dwie dwórki o obco brzmiących imionach, być może więc Czochna i Gałga były Węgierkami (Rachunki Jagiełły i Jadwigi, s. 194). Po ślubie Elżbiety Rakuskiej z królem Kazimierzem odesłano niewiasty (zwane matronami), które towarzyszyły jej w podróży do Polski (o czym pisał Długosz pod 1454 r. — Annales, lib. 12 [2003], s. 176-177]). Wspomniane matrony były szanowanymi wdowami po dostojnikach. Zob. przykładowo opis wyjazdu królewny Jadwigi z Polski do narzeczonego do Bawarii, zamieszczony przez Długosza pod datą 10 października 1475 r. — do Polski wróciły matrony i panny. Przy okazji Długosz uświadamiał czytelnikom, że misje takie były i zaszczytne, i niebezpieczne. Polacy zostali hojnie obdarowani w Bawarii, ale też nabawili się szerzącej się wówczas w Niemczech choroby $\mathrm{i}-$ jak pisał Długosz — wielu z nich zmarło po powrocie do Krakowa (Annales, lib. 12 [2005], s. 366-367).

95 JAN z Komorowa: Kronika..., s. 306 - wzmianka o lekceważeniu przez Helenę ochmistrzyni miała pewnie usprawiedliwić zdradę owej księżnej, która doniosła na swoją panią, że ta zamierza wyjechać do Moskwy. O dworze Heleny zob. K. PietKiewicz: Dwór litewski..., s. 94-95 - tu podano, że w jego skład wchodzili: kanclerz, klucznik, krajczy, kuchmistrz, ochmistrz, pisarz, namiestnik jej dóbr oprawnych, dwórki wraz z ochmistrzynią oraz pokojowcy. Po ślubie z Aleksandrem pozostały przy niej tylko dwórki greckiego wyznania do posług domowych, które sama wybrała, nadto mąż dał jej własne sługi, którzy mieli czynić wszystko według jej woli i rozkazu (Daniłowicz, T. 2, nr 2083, 2085, 2088, 2089). Kuchmistrz Wojciech Janowicz Kłoczko wyznaczony został zaraz po przyjeździe Heleny do Wilna w 1495 r. Była to zapewne decyzja strony polskiej, ponieważ jak wpisano w moskiewskiej księdze poselstw, nie był on greckiego wyznania i — jak zaznaczono - nie miał żony (SRIO, T. 35, s. 171). 
Niewątpliwie, to ci nieliczni pozostali z grona prawosławnych dworzan i dwórek uczestniczyli potem we wszystkich obrzędach pogrzebowych Heleny. Składały się na nie: umycie ciała, założenie nowego ubrania (symbolizujące nieśmiertelność), nakrycie ciała sawanem, czyli białym lnianym płótnem (symbol chrztu i przynależności do Cerkwi), i soborowanie ciała, czyli namaszczenie olejkiem (pomagało przejść do nieba bez grzechu). Pogrzeb odbywał się trzeciego dnia po śmierci, a do tego dnia modlono się przy zmarłym, przyjeżdżał duchowny i codziennie odmawiano Panichidę, czyli modlitwę za zmarłych. W dniu pogrzebu przy dźwięku dzwonów przenoszono trumnę do cerkwi, stawiano na katafalku i uchylano wieko, które zamykano po zakończeniu liturgii pogrzebowej oraz pożegnaniu ze zmarłym.

Trumna z ciałem Heleny została złożona w cerkwi Przeczystej Bogurodzicy w Wilnie. Pogrzeb zaś organizowali, starannie, najważniejsi urzędnicy litewscy, panowie rady. Wiemy o tym z listu kanclerza Mikołaja Radziwiłła oraz marszałka wielkiego Stanisława Piotrowicza (Kiszki) wysłanego do metropolity kijowskiego Józefa Sołtana 25 stycznia 1513 roku. Informowali oni o śmierci królowej i wielkiej księżnej oraz pisali, że ciało jej zostanie przewiezione z Brasławia do Wilna 25 lub 26 stycznia, a wszyscy poddani hospodarscy jej żałują.

Decyzja o eksportacji ciała Heleny z Brasławia do Wilna zapadła natychmiast, zapewne bez żadnych wątpliwości i dyskusji. Pochówek w cerkwi Przeczystej musiał być ustalony wcześniej, może z samą Heleną, metropolitą litewskim i zwierzchnikiem cerkwi. Kto wcześniej tam spoczął? Książęta? Szlachta? Biskupi, duchowni wraz z żonami i dziećmi? W murach świątyni złożono ciało księżniczki Julianny, żony księcia Olgierda i matki Jagiełły ${ }^{96}$. Nic więcej nie wiadomo. Podobnie nie mamy informacji o sposobie pochówku, usytuowaniu grobu i jego wyposażeniu.

Mikołaj Radziwiłł i Stanisław Piotrowicz prosili, by metropolita pospieszył na pogrzeb do Wilna, ale jeśli trzeba będzie, to każą jeszcze dzień czekać, „bo to jest rzecz waszej miłości duchowna”, a po przyjeździe metropolity uzgodnią wspólnie, „gdzie i jakim obyczajem ciało królowej ma zostać złożone" "97. Dopowiem, że wszelki ślad po grobowcu Heleny zaginął, ponieważ cerkiew była kilkakrotnie niszczona przez pożary, a ostatecznej destrukcji uległa podczas powstania kościuszkowskiego. W XIX wieku świątynię rozebrano, a na jej miejscu zbudowano nową. Zachowały się tylko fragmenty gotyckich murów ${ }^{98}$.

${ }^{96}$ B. Manyś: Uroczystości rodzinne w Wilnie w czasach Augusta III (1733-1763). Poznań 2012, s. 72 .

${ }_{97}$ AZR 2, nr 83, s. 110-111.

${ }^{98}$ K. Walejko [i in.]: Praktyczny przewodnik po Wilnie. Suwałki 2003, s. 99. J.I. KraSzewski (Wilno..., T. 3, s. 63) pisał, że „żaden pisarz o miejscu spoczynku nie wie”, i przypuszczał, iż może po zajęciu w 1655 r. miasta przez wojska carskie trumna z ciałem Heleny 
Czy wyznawcy obrządku łacińskiego uczestniczyli w uroczystościach pogrzebowych? Nie wiadomo. Podczas pobytu w Wilnie Elżbiety Rakuskiej Helena towarzyszyła jej tylko do bramy katedry wileńskiej, sama zaś szła do cerkwi ${ }^{99}$. W XVI wieku we Lwowie prawosławni Rusini odprowadzali ciało zmarłego wyznawcy obrządku łacińskiego tylko do bramy cmentarnej - podobnie czynili łacinnicy wobec zmarłego prawosławnego. Z kolei prawosławni członkowie bractw i cechów płacili takie same składki na uroczystości cechowe jak łacinnicy, a więc także na nabożeństwa cechowe. Nie uczestniczyli w nich jednak, więc składki te były formalnie traktowane jako kary, które płacili wszyscy członkowie bractw i cechów niespełniający obowiązków religijnych ${ }^{100}$. Domyślamy się natomiast, że Helena była na uroczystościach pogrzebowych męża $\mathrm{w}$ katedrze wileńskiej, ponieważ któż, jak nie ona, włożyłby do trumny zmarłego Aleksandra dwa bliźniacze pierścionki ${ }^{101}$.

Zapytać jeszcze należy: czy księżna miała jakikolwiek wpływ na stosunki państwa z Cerkwią? Anna Leonidówna Choroszkiewicz w swym wyważonym artykule pisze o zaostrzeniu polityki wobec prawosławia już w pierwszych latach panowania Aleksandra ${ }^{102}$. Znane przykłady wspierania przez tego władcę Cerkwi czy duchowieństwa są rzeczywiście nieliczne i zdają się potwierdzać tę opinię.

15 lipca 1496 roku w Wilnie na prośbę bojarów i mieszczan połockich Aleksander wziął w opiekę monaster św. Mikołaja w Połocku, 13 kwietnia 1497 roku przysądził władyce połockiemu sporne ziemie, a pod koniec 1497 roku dokonał znaczącego nadania na rzecz klasztoru św. Mikołaja w Kijowie. 5 lutego 1498 roku wydał dokument, na mocy którego zniesiono wszystkie nowe podatki niezgodne $\mathrm{z}$ dawnym zwyczajem (duchowieństwo wileńskie uskarżało się, że metropolita wbrew dawnym zwyczajom ściąga zbyt wysokie podatki lub wprowadza nowe daniny, których wcześniej nie było). 20 marca 1498 roku Aleksander potwierdził zapisy na rzecz cerkwi wołkowyskiej i podobnie 17 marca oraz 6 kwietnia 1497 roku, a także 20 marca 1499 roku metropolita kijowski Józef I Bułharynowicz (zwolennik unii kościelnej) otrzy-

została zabrana do Moskwy. Wydaje się jednak mało prawdopodobne, by nie zachował się żaden przekaz o ponownym pochówku w tym mieście.

99 J. GARBACIK: Helena..., s. 360.

100 J. Ptaśnik: Obywatelstwo miejskie w dawnej Polsce. (Na tle stosunków Krakowa). „Przegląd Warszawski” 1921, R. 1, T. 1, nr 2, s. 153-154; K. ChODYNicki: Kościót prawostawny..., s. 98.

${ }^{101}$ O odnalezieniu takowych w trumnie króla zob. M. LimANowski: Szczątki Aleksandra Jagiellończyka w katedrze wileńskiej. „Ilustrowany Kurier Codzienny” z 26 listopada 1931 r., s. 2.

102 А.Л. Хорошкевич: Жалованые..., s. 54; Z. WолткошіАк: Dyplomatyka..., s. 275277. 
mał potwierdzenie tzw. ustawy cerkiewnej Jarosława ${ }^{103}$, która dawała Cerkwi prawosławnej i metropolicie daleko idące przywileje ekonomiczne oraz sądownicze, również w odniesieniu do wyznawców obrządku łacińskiego. 19 marca 1501 roku Aleksander zapisał władyce połockiemu swoich poddanych hospodarskich w trzech wyliczonych wsiach, którzy odtąd mieli spełniać wszystkie powinności w dobrach cerkwi św. Zofii. 1 marca 1505 roku na prośbę władyki smoleńskiego wystawił przywilej, w którym nakazywał m.in. „nie uciskać greckiej wiary, nie przywłaszczać ziemi i wód cerkiewnych"104. W Bersztach 5 marca (bez daty rocznej) zwolnił monaster Przeczystej Bogurodzicy w Trokach z wszelkich powinności na rzecz metropolity kijowskiego, co potwierdził potem Zygmunt I. Wiadomo też, że gdy książęta pińscy Iwan i Fiodor zaczęli bez zgody biskupa turowsko-pińskiego budować świątynie i mianować kapłanów bez zezwolenia biskupów, wówczas Aleksander pod karą 3000 kóp groszy litewskich zabronił budowania kościołów bez zgody władzy duchownej i zakazał wtrącania się do spraw kościelnych ${ }^{105}$.

Tradycja przypisuje wstawiennictwu Heleny mianowanie Jonasza III Rusina metropolitą kijowskim (litewskim, 1502-1507) po śmierci Józefa I Bułharynowicza ${ }^{106}$. Powstanie tej tradycji było zapewne spowodowane tym, że Jonasz był wcześniej spowiednikiem Heleny (król miał prawo podawania, czyli wskazywania, kandydata, którego potem zatwierdzał patriarcha Konstantynopola).

10320 III 1499: AZR 1, nr 166 = Daniłowicz, T. 2, nr 2105. Na prośbę arcybiskupa połockiego i witebskiego Łukasza Aleksander potwierdził cerkwi zwój Jarosława ponownie w $1503 \mathrm{r}$. (Daniłowicz, T. 2, nr 2158).

${ }^{104}$ Daniłowicz, T. 2, nr 2164.

105 Беларускі архіў. Т. 2: Літоўская метрыка (XV-XVI cm.). Мінск 1928, № 216217, s. 158-159; Собраніе древних грамот и актов городов Вильны, Ковна и Трок, православных монастырей, иерквей и по разным предметам. Т. 1. Вильна 1843, № 50, s. 142; П.А. Муханов: Сборник Муханова. [Акты по истории России за 1393-1729 г2.]. Москва 1836, № 69 s. 97-98 (przykłady za: A. Winiarska: Rola..., s. 21-22); Русская историческая библиотека. Т. 27: Литовская Метрика. Отдел первый. Часть первая: Книги записей, т. 1. С.-Петербург 1910, № 118, Кол. 639; № 152, Кол. 672-674 oraz № 169, Кол. 693-694; AZR 1, nr 144, 151, 152, 157; AZR 2, nr 109; Daniłowicz, T. 2, nr 2164.

${ }^{106}$ Informacja o wstawiennictwie Heleny wpisana została do Kroniki tawry supraskiej (w: Археографический сборник документов..., s. 37). Zob. też ostatnio A. Mironowicz: Kościót prawosławny w Polsce. Białystok 2006, s. 195; wcześniejsze opinie zestawił K. CHODYNICKI: Kościót prawostawny..., s. 120 i przyp. 1. 


\section{Relacje Heleny z Kościołem lacińskim i jego wyznawcami}

Polskie duchowieństwo zajmowało wobec Heleny dwa stanowiska. Jedni zgadzali się na pozostanie przez nią przy greckiej wierze z jednoczesnym uznaniem prymatu papieskiego (bernardyni wileńscy), inni (kapituła krakowska i Uniwersytet Krakowski) żądali przejścia na wiarę łacińską, a więc powtórnego chrztu, tym razem w obrządku Kościoła zachodniego, i ta ostatnia opinia dotyczyła wszystkich wyznawców prawosławia na terenie Litwy ${ }^{107}$. Spór ten opisał pod 1494 rokiem Jan z Komorowa ${ }^{108}$. Głównym rzecznikiem rebaptyzacji był Jan Sacranus z Oświęcimia - filozof, profesor teologii i rektor Uniwersytetu Krakowskiego (w 1505 roku spowiednik Aleksandra Jagiellończyka, bliski Fryderykowi Jagiellończykowi). Na zamówienie biskupa wileńskiego Wojciecha Tabora napisał on (ok. 1501 roku), w związku z zamierzonym poselstwem do papieża, traktat pt. Elucidarius errorum ritus $R u$ thenici - o błędach religijnych prawosławnych. Zajął w nim stanowisko wrogie wyznaniu greckiemu i przeciwne związkom małżeńskim między osobami różnych wyznań (a więc zbieżne z poglądami swojego mocodawcy, biskupa Tabora). Środowisko uniwersyteckie twierdziło, że unia florencka czyni zbyt duże ustępstwa wobec prawosławnych i utrudnia szerzenie wiary łacińskiej na Litwie ${ }^{109}$. Z kolei król Aleksander uczynił w 1502 roku Jana Laskiego sekretarzem swojej kancelarii koronnej (3 maja 1502-listopad 1503) i zabrał go na Litwę, a Łaski był zwolennikiem poglądów Sakrana. Sądzi się, że to Fryderyk Jagiellończyk powierzył Łaskiemu misję nawracania Heleny na wiarę łacińską ${ }^{110}$.

107 K. Pietkiewicz (Wielkie Księstwo..., s. 171) podkreślał, że przeciwnikami unii byli też ci spośród panów litewskich, którzy przyjęli obrządek łaciński: „Dla biskupa Tabora, jak i dla panów litewskich najistotniejsze było ograniczenie władzy monarszej na rzecz rady. Współgrało to znakomicie z dążeniem do hegemonii Kościoła katolickiego, który był jednocześnie wyznacznikiem ich tożsamości grupowej. W tej sytuacji unia kościelna i pojawienie się na scenie politycznej kardynała unity z rzeszą biskupów i możnowładców wyznania unickiego jako czynnika równoprawnego, zagrażało interesom możnowładztwa litewskiego”. Jan z Komorowa zauważył podobną tendencję, choć powody tłumaczył odmiennie: „Chociaż biskupi mają pełną władzę przyjmowania prawosławnych na łono Kościoła i do posłuszeństwa matce Kościołowi, nie działają jeszcze skutecznie, prawdopodobnie dlatego, że nie widzą w tym korzyści finansowych dla siebie i nie zależy im zupełnie na dobru i zbawieniu dusz" (JAN z KomorowA: Kronika..., s. 260).

108 Jan z Komorowa: Kronika..., s. 258-259.

109 U. Borkowska: Bracia mniejsi i prawosławie. W: Franciszkanie w Polsce średniowiecznej. Cz. 1: Franciszkanie na ziemiach polskich. Red. J. KŁoczowsKi. Kraków 1983, s. 401-402; M. MACISZEwSKA: Klasztor bernardyński w społeczeństwie polskim 1453-1530. Warszawa 2001, s. 37.

110 A. Winiarska: Rola ..., s. 24. 
W 1501 roku polskie poselstwo pojechało do Rzymu. Na jego czele stanął Erazm Ciołek. Spędził tu 9 miesięcy (od 2 marca do 2 grudnia 1501 roku $^{111}$ ), a towarzyszył mu Iwan Sapieha (był pisarzem, a od 1502 roku kanclerzem Heleny). Obaj byli zwolennikami stanowiska bernardynów wileńskich. Z korespondencji Aleksandra z kardynałem Carvajalem wynika, że chodziło głównie o „powrót Rusinów mieszkających na Litwie na łono Kościoła łacińskiego”, ponieważ na Litwie ok. 3/4 mieszkańców stanowili prawosławni, co groziło powiększaniem wpływów Moskwy na tych ziemiach. Temat konwersji Heleny nie był oficjalnie poruszany, by nie narażać się na gniew Iwana III ${ }^{112}$.

Dnia 26 kwietnia 1501 roku Aleksander otrzymał odpowiedź papieską na swoje poselstwo. Papież orzekł, że nie jest wymagany ponowny chrzest tych, którzy przejdą z obrządku ruskiego na rzymski. Zezwalał metropolicie kijowskiemu wznosić świątynie murowane i przyjmować osoby chętne do jedności wiary z Kościołem rzymskim, jeżeli zachowają dekrety soboru florenckiego.

Papież wypowiadał się kilkakrotnie na temat wyznania Heleny i jego stanowisko ewoluowało. Listy kierował do Aleksandra (7 maja i 8 czerwca 1501 roku), Fryderyka Jagiellończyka (26 listopada 1501 roku — papież żądał stanowczo, by Aleksander oddalił Helenę, jeśli ta nie przyjmie wiary łacińskiej ${ }^{113}$ ) i do biskupa wileńskiego Wojciecha Tabora ${ }^{114}$. W bulli z 23 sierpnia 1501 roku pt. Altitudo divini consilii papież Aleksander VI stwierdził, że w przypadku Heleny nie jest konieczna rebaptyzacja, podobnie zresztą nie stawiał tego wymogu wobec całej ludności prawosławnej Litwy. Warunek był jeden: uznanie prymatu papieża, a w razie odmowy — separacja małżonków, a dokładniej — oddalenie żony. Papież zwolnił też Aleksandra od przysięgi złożonej Iwanowi III, dotyczącej poszanowania prawosławnego wyznania Heleny. Tutaj od razu dopowiem, że kapituła krakowska poszła dalej niż papież, ponieważ zażądała od księżnej chrztu w obrządku łacińskim. To stanowisko oburzyło Aleksandra. Prosił on swojego brata, kardynała Fryderyka, o interwencję. Pisał: „[...] kapituła toczy ubliżające rozprawy o moim małżeństwie, zamiast sprawę traktować delikatnie w myśl wskazówek papieskich" (list z 18 marca 1502 roku) ${ }^{115}$. Zaostrzenie stanowiska papieża i kapituły nastąpiło po śmierci króla Jana Olbrachta (zmarł 17 czerwca 1501 roku), w związku z perspektywą objęcia tronu w Polsce przez Aleksandra. Stanowczo zabrzmiał wówczas głos papieża Aleksandra VI, który nakazywał wielkiemu księciu Aleksandrowi wykluczyć Helenę „od stołu i łoża”, jeśli trwać będzie ona przy „schizmatyckiej” wierze, a kardynała

111 L. BirkenMAJER: Zapiski historyczne wśród starych almanachów Biblioteki Jagiellońskiej. Kw. Hist. 1902, T. 16, s. 449.

112 H. Folwarski: Erazm Ciołek. Biskup i dyplomata. Warszawa 1935, s. 41.

113 Vetera monumenta Poloniae et Lithuaniae historiam illustrantia. T. 2. Ed. A. THEINER. Romae 1861, nr 312.

114 Tamże, nr 303, 309, 312.

115 Akta Aleksandra..., nr 60. 
Fryderyka prosił papież, by osobiście dopilnował sprawy nawrócenia księżnej, ponieważ — jak podkreślał - nie można pozwolić, by osoba, która nie chce być katoliczką, została królową (,que christianum nomen et katholicas institutiones abhorret et fugit, tam insignis potentisque Regni regina dicatur"). Stanowisko Kurii złagodzone zostało dopiero w 1505 roku, gdy Juliusz II zezwolił Helenie na pozostanie przy własnej wierze, dopóki żyje jej ojciec ${ }^{116}$.

Obok tych rozgrywających się na poziomie dysput akademickich czy działań dyplomatycznych sporów o prawosławne wyznanie żony Aleksandra toczyło się codzienne życie przepełnione spotkaniami Heleny z katolikami. Była wśród nich królowa-matka Elżbieta Rakuska, od początku niechętna Helenie (jej stosunek do synowej chyba nigdy się nie zmienił). Elżbieta dotarła do Wilna na ślub syna $\mathrm{z}$ Heleną spóźniona, nie uczestniczyła $\mathrm{w}$ uroczystościach ${ }^{117}$. Inne powody zdecydowały o nieobecności Heleny na koronacji Aleksandra w Krakowie 12 grudnia 1501 roku. Wiadomo było, że ona nie zostanie koronowana.

O kontaktach Heleny z polsko-litewskimi poddanymi wiemy niewiele. Nie ma na ten temat wzmianek $\mathrm{w}$ - jak zawsze króciuteńkich — zapiskach rachunkowych ani w podługoszowych kronikach. Kontynuatorzy Długosza pisali o Helenie niewiele i bez emocji. Najczęściej są to zwięzłe informacje o jej ślubie z Aleksandrem, o tym, że nie została koronowana, ponieważ pozostała przy greckiej wierze; podawano też jako powód najazdów Moskwy na Litwę to, że Aleksander nie wybudował dla księżnej cerkwi na zamku wileńskim (powtarzano zatem oficjalny powód konfliktów głoszony przez Moskwę). Więcej napisał o niej jedynie Marcin Bielski (żył w latach 1494-1575, jego kronika „Wszystkiego świata” ukazała się po raz pierwszy w 1551 roku): „[...] miała na zamku krakowskim swoją kaplicę, gdzie obyczajem ruskim nabożeństwo swoje odprawowała. Nie bardzo to wdzięcznie od króla przyjmował papież [...], a wszakże, aby z nią mógł mieszkać, posłał mu na to dispensacio,

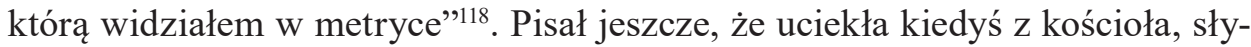
sząc organy, które zwała dudami. Ucieczki zapewne nie spowodował instrument - wprawdzie w cerkwiach nigdy nie używano organów czy innych instrumentów muzycznych, ale dźwięk organów mogła znać ${ }^{119}$. Decydujący był zakaz ojca, by nie odwiedzała kościołów łacińskich.

116 Vetera monumenta..., nr 310-312, 319, 351. Zob. też: K. PietKiewicz: Wielkie Księstwo..., s. 170 i przyp. 94.

117 Elżbieta Rakuska w marcu 1495 r. była w Wilnie wraz z synami: Janem Olbrachtem i Fryderykiem, oraz córkami: Barbarą i Elżbietą (spóźnili się na ślub Aleksandra z Heleną). Aleksander wspominał w listach z kwietnia 1496 r. o pobycie u niego w Wilnie matki oraz braci - Olbrachta i Fryderyka (AZR 1, nr 135). Maciej Stryjkowski pisał w swojej kronice (wydanej w 1582 r.), że Elżbieta pojechała na Litwę z synem Fryderykiem oraz córkami Barbarą i Elżbietą (M. STRYjKowsKI: Kronika polska, litewska, żmudzka i wszystkiej Rusi. T. 2. Warszawa 1846, s. 301).

118 M. BIELSKI: Kronika polska..., s. 494.

119 Zob. przyp. 81. 
Aleksander i Helena wiele razem podróżowali. Sądzić można, że księżna podejmowana była w Polsce godnie, może wzbudzała ciekawość, ale nikt nie napisał, by ganiano za jej powozem z okrzykiem ,czarownica”, jak to przydarzało się później w Krakowie Barbarze Radziwiłłównej. Nieco więcej wiemy o jej wizytach w łacińskich kościołach i klasztorach. W 1504 roku Aleksander i Helena byli razem w klasztorze na Jasnej Górze i tamtejsza ikona Matki Bożej wywarła na księżnej tak duże wrażenie, że jeszcze w tym roku Aleksander ofiarował paulinom jasnogórskim cztery bałwany soli rocznie z żupy wielickiej, a nadanie to wyjednała Helena (,ad devotionem, quam ser[enissima] princeps domina Elena, consors nostra charissima, ad ecclesiam monasterii beat[issime] Virg[inis] Marie Montis Clari in Czenstochowa gerit") ${ }^{120}$.

Wiemy, że Helena wspierała klasztor bernardynów w Wilnie. W nim po śmierci Aleksandra zdeponowała osobisty skarbiec. Pisał o tym ówczesny gwardian klasztoru Jan z Komorowa: „U naszych braci w Wilnie złożyła pewne skarby, mianowicie czternaście wielkich skrzyń ze złotem i srebrem. Były tam misy duże i małe, perły i drogie kamienie, złote puchary, zagrabione dywany wyszywane złotem i około trzysta pięćdziesiąt szat obramowanych purpurą" ${ }^{\prime 21}$. Kronikarz zapewniał, że depozyt „widział na własne oczy”. Dalej pisał, że Helena spotkała się, za zgodą króla Zygmunta, w swoim oprawnym Bielsku (Podlaskim) z posłami Iwana III. Oświadczyła im, że zamierza wyjechać do Moskwy i najpierw uda się ze skarbami oraz z całym dworem do swojego zamku w Bracławiu. Skarb został odesłany do króla Zygmunta I, a ponieważ panowie litewscy powiedzieli Helenie, że jej plan ucieczki poznali dzięki gwardianowi bernardynów Janowi z Komorowa, księżna ,śmiertelnie rozgniewała się także na gwardiana i na braci, cofnęła swoją pomocną rękę w potrzebach braci, czego przedtem nie czyniła"122. Cała sprawa znana jest

${ }^{120}$ Akta Aleksandra..., s. 415 = ZDPaul, T. 2, nr 132.

121 JAN z Komorowa: Kronika..., s. 305-307. W innym miejscu Jan z Komorowa wspomniał, że na wesele swoich dwórek Helena odebrała od bernardynów z owych skrzyń srebrne naczynia, mianowicie czary do picia (tamże, s. 307). Część skarbu księżnej przechowywano też w cerkwi Przeczystej w Wilnie; po śmierci władczyni na polecenie panów litewskich przeniesiono stamtąd dwie skrzynie do klasztoru bernardynów wileńskich: „W jednej skrzyni było 16060 dużych groszy [sic! Mamy tu do czynienia z ewidentnym błędem tłumacza w oryginale łacińskim mowa o 16000 kóp szerokich groszy: „sedecim milia sexagenarum latorum grossorum", zob. JAN z Komorowa: Memoriale Ordinis Fratrum Minorum a fr. Ioanne de Komorowo compilatum. Ed. X. Liske, A. Lorkiewicz. W: MPH, T. 5, s. 309 - A.K.] i 2000 florenów w złocie. W drugiej, która została otwarta, było złoto w sztabach, klejnotach, wielu łańcuchach, 16 pasków czystego złota i ok. 400 kosztownych pierścieni, cztery pary trzewików wspomnianej królowej z perłami i drogimi kamieniami, które, jak mówili panowie, miały wartość 7000 florenów. Wspomniana skrzynia, tu opisywana, miała wewnątrz około trzydziestu małych skrzyneczek, jedne srebrne, drugie pozłacane, inne z berylu, jeszcze inne z różnych kamieni i metali, w których były pojedyncze duże perły i kosztowne diamenty" (JAN z Komorowa: Kronika..., s. 309).

122 JAN Z Komorowa: Kronika..., s. 307. 
tylko z opisu Komorowskiego, stąd w literaturze powątpiewa się w jej prawdziwość ${ }^{123}$.

Helena co najmniej raz odwiedziła kościół i klasztor Augustianów w Kazimierzu koło Krakowa, zostawiając tam 11 września 1506 roku drobną ofiarę mszalną 5 groszy i 6 oboli („Item a regina de offertorio quinque grossos et sex obulos") ${ }^{124}$. Zapis z 11 września oznacza, że po pogrzebie Aleksandra księżna przybyła spiesznie do Krakowa i wstąpiła do klasztoru oraz kościoła, które często odwiedzali jej zmarły mąż i teściowa (we wrześniu 1506 roku nie było w Polsce innej osoby, którą można by nazwać królową). Kościół ten słynął jako miejsce kultu Matki Bożej oraz Chrystusa Miłosiernego, przedstawionych na dwóch obrazach znajdujących się w krużgankach klasztornych. Może Helenie bliski był też kult św. Jana Jałmużnika, przedstawionego wraz z grupą świętych anachoretów Kościoła wschodniego w poliptyku ustawionym u zbiegu krużganka północnego z zachodnim (Aleksander czynił starania u papieża Juliusza II o uzyskanie odpustów dla modlących się do tego świętego) ${ }^{125}$.

${ }^{123}$ M. Duczmal (Jagiellonowie. Leksykon biograficzny. Kraków 1996, s. 259) uznała przejęcie skarbu przez Zygmunta I za nieprawdopodobne, ponieważ sprawa nie znalazła odbicia w innych źródłach. Por. też F. PAРéE, rec. z: Е. Церетели: Елена Иоанновна..., s. $310-313$.

${ }^{124}$ Dnia 3 kwietnia 1504 r. w rachunkach klasztoru Augustianów przy kościele pw. św. Katarzyny na Kazimierzu koło Krakowa zanotowano, że królowa zostawiła ofiarę mszalną, a na marginesie, ręką z XVII w., napisano: „Regina uxor Alexandri ducis Lituanie solvit”. W tym miejscu niewątpliwie chodzi jednak o Elżbietę Rakuską, ponieważ w tym czasie Helena wraz z Aleksandrem podróżowali przez Piotrków (przyjazd 31 stycznia, pobyt 6 tygodni) do Prus (Toruń, kwiecień/maj). Zob. Dochody i wydatki konwentu braci eremitów św. Augustyna przy kościele św. Katarzyny w Kazimierzu. Wyd. J. JeloneK-Litewka, W. KoLAK, C. Pirożyński, Z. Wojas. T. 1: 1502-1505. Kraków 2002, s. 35. Jeden z wydawców opublikował wcześniej fragmenty tych rachunków oraz z początków panowania Zygmunta I i we wstępie pisał, że nie wiadomo, czy pod określeniem „regina” kryje się Elżbieta Rakuska, czy Helena. Mszę za zdrowie króla dnia 17 maja 1502 r. zamówić mogła jednak tylko Elżbieta, ponieważ Helena w tym czasie była już w podróży z Aleksandrem (3 maja razem opuścili Kraków i podróżując przez Nowy Korczyn, Sandomierz oraz Lublin, wjechali przez Brześć Litewski na Litwę). Zob. Dary królewskie dla kościoła i klasztoru Augustianów w Krakowie. Oprac. W. KolaK. „Krakowski Rocznik Archiwalny” 2001, T. 7, s. 138, nr 10 (17 V 1502 r.); s. 141, nr 42 (11 IX 1506 r.); G. RutKowska: Podróże polskich królowych..., s. 189-190 (itinerarium Heleny).

${ }^{125}$ W. KolaK: Klasztor Augustianów przy kościele św. Katarzyny w Krakowie do połowy XVI wieku - fundacja, rozwój uposażenia i rola kulturalna. Kraków 1982, s. 109-117. 


\section{Podsumowanie}

Helena, podobnie jak inne żony Jagiellonów, które w XV i XVI wieku przybyły do Polski z Austrii (Elżbieta Rakuska, Anna Cylejska, Elżbieta Habsburżanka), Węgier (Barbara Zápolya) i Włoch (Bona Sforza), weszła poprzez małżeństwo polityczne do tej dynastii. Zapisała się dobrze w pamięci polskich wyznawców prawosławia jako ich opiekunka i ta pamięć przekazywana jest z pokolenia na pokolenie. Natomiast stosunek do niej wyznawców obrządku łacińskiego mógł być tylko jeden - misjonarski. Dar Bożego błogosławieństwa obejmował tylko ich świat, poza którym pozostawał świat niewiernych, także schizmatyków czy heretyków. Ponieważ Chrystus umarł za wszystkich, więc Kościół łaciński realizował misję włączania do Bożego świata tych, którzy pozostawali poza prawdziwym Kościołem Chrystusowym. Wysiłki misjonarskie musiały być zatem podejmowane również wobec Heleny i innych wyznawców prawosławia, żyjących zwłaszcza na terenach Litwy. Nie była to jednak nieustająca opresja. Wielokrotne zapewnienia Aleksandra Jagiellończyka kierowane do jej ojca, że Helena nie jest zmuszana do zmiany obrządku, były z pewnością prawdziwe. Ona też przekonywała ojca, matkę i swoich braci, że ma pełną swobodę wyznania. Wielonarodowościowa i wielokulturowa Polska Jagiellonów przyjęła Helenę z nadzieją na pokój z Moskwą, była ona tytułowana przez współczesnych królowąa ${ }^{126}$, czasem schi-

${ }^{126}$ Zob. G. Rutkowska: Podróże polskich królowych..., s. 189, przyp. 44. Zebrane tam przykłady nazywania Heleny królową (z lat 1502, 1509 i 1513) można uzupełnić o kolejne z lat 1508 i 1510 (Wilno, 9 marca [1508] indykcja 11: królowa Helena zawiadamia namiestnika sadowskiego Jakuba Kuźmicza, że dała bojarowi Grigorijowi Putoszyńskiemu ziemię [Sadowie] na Wołyniu, którą on kupił od Bogdana Gostkowskiego; Birsztany, 3 czerwca [1510] indykcja 13: daje bojarowi Putoszyńskiemu ziemię Sadowie i dwóch ludzi; Архивъ Юго-Зарадной Россіи, издаваемый Временною Коммиссіею для разбора древнихъ актовъ. Ч. 8. Т. 4. Кіевъ 1907, s. 286 - 287); tytułu królowa używała też jako wdowa (w dwóch swoich listach, z 17 listopada i 12 grudnia [1512] indykcja 1, oba wystawione w Oniksztach i oba dotyczyły jej dworzanina Bartłomieja, Bortka Stankowicza; w pierwszym liście, skierowanym do ciwunów i namiestników żmudzkich, wzywała do wymierzenia sprawiedliwości tym bojarom i ludziom, którzy napadli, ograbili i spalili dwór Stankowicza, na końcu zaś zaznaczyła, że gdyby z jakichś powodów sprawiedliwość nie została wymierzona, wówczas obie strony mają stawić się przed nią i ona będzie sądzić; w drugim liście informowała namiestnika dyrwiańskiego, że przywróciła Stankowiczowi posiadanie 20 ludzi wraz z ich ziemiami w powiecie (wołost) dyrwiańskim, tych ludzi niegdyś od niego „oddaliła”, a teraz ponownie oddaje - AZR 2, nr 81 i 83, s. 108 - 110); według wydawcy przywileju Heleny dla Iwana Sapiehy z 31 stycznia 1509 r. przy dokumencie tym znajdowały się resztki pieczęci z uszkodzonym napisem w otoku: „[...] Polonie Magna Ducis. Lituan. Rus. Prus.” (Собрание государственных и частных актов, касаюшихся истории Литвы и соединенных с ней владений [от 1387 до 1710 года]. Ред. М. Крупович. Ч. 1. Вильно 1858, nr 27, s. 33); z dokumentu Jana Filipowicza, kusto- 
zmatycką królową (Jan z Komorowa: „dux Elena scismatica albo scismatica regina" ${ }^{\prime 27}$ ).

Helenę traktowano w Polsce godnie jako żonę króla, o czym sama przekonała się, towarzysząc mężowi w podróżach po kraju w 1502 (byli m.in. w Krakowie, Nowym Korczynie, Sandomierzu, Lublinie), 1504 (odwiedzili m.in. Piotrków, Toruń, Elbląg, Gdańsk, Malbork, Łęczycę, Częstochowę) i może też w 1505 roku $^{128}$. Królowa „faktyczna”, de iure, była jednak tylko jedna — jej teściowa Elżbieta Rakuska. Statusu Heleny nie mogło zmienić samo tylko tytułowanie jej królową przez króla Aleksandra, po jego śmierci czasem również przez jego brata i następcę Zygmunta I, czy używanie przez nią tytułu królowej w swoich listach i dokumentach.

Aleksander w swoim testamencie spisanym w 1506 roku powierzał Helenę opiece brata Zygmunta i panów litewskich — ,jej sprawy i prawa, aby taką miała obronę i ochronę jak za życia jego i w takiej uczciwości i poszanowaniu oraz przy prawach i wolnościach zachowana była"129.

sza i kanonika wileńskiego, wystawionego w Wilnie 12 lutego [1509] indykcja 12, pochodzi informacja, że wystawca sprzedał swój plac „w zamku wileńskim z sklepem murowanym” „królowej” Helenie za 90 kóp groszy (Lietuvos Metrika. Knyga Nr. 1 (1380-1584). Užrašymu knyga 1. Vilnius 1998 (dalej: LM 1), nr 108); w Oniksztach 14 lipca [1512] indykcja 15 wystawiła jako królowa dokument z pieczęcią nadający wieczyście jej dworzaninowi Wasylowi Hrehorowiczowi ziemię opustoszałą zwaną Opikowszcziną (LM 1, nr 524). Tytuł ten pojawia się także w liście litewskiej rady z 25 stycznia 1513 r., która zawiadamiała metropolitę kijowskiego Józefa Sołtana o śmierci Heleny i zapraszała do Wilna na pogrzeb „królowej” AZR 2, nr 83, s. 110-111. Z kolei król Zygmunt I w 1514 r. dał Sadowie kniaziowi Iwanowi Jurjewiczowi Zasławskiemu (Żesławski), którą „trzymała” zmarła królowa i wielka księżna Helena (tamże, s. 298); władca ten w latach 1513 i 1522 potwierdził darowizny królowej Heleny w postaci dworu Iwanowskiego i ludzi w Ciecierynie na rzecz Wasyla Hrehorowicza (LM 1, nr 521 i 522). Helena nie używała tytułu królowej z własnej inicjatywy. K. PietKieWICZ (Wielkie Księstwo..., s. 171) pisze, że „Aleksander zmusił otoczenie do tytułowania Heleny królową". Nazwał ją królową np. w swoim dokumencie z 1503 r. (Daniłowicz, T. 2, nr 2153).

127 Jan z Komorowa: Memoriale..., s. 305, 307.

${ }_{128}$ G. Rutкowska: Podróże polskich królowych..., s. 190. Latopis hustyński pod 1501 r. informował o wspólnej podróży Aleksandra i Heleny z Wilna do Krakowa, a pod 1502 r. na Litwę (obie wiadomości za: M. Bielski: Kronika polska..., s. 494, 495; H. Suszko: Latopis hustyński..., s. 224).

129 M. BALIŃski: Historia miasta Wilna. T. 2. Wilno 1836, s. $205=$ Daniłowicz, T. 2, nr 2174. 


\section{Bibliografia}

\section{Źródła drukowane}

Acta Tomiciana. T. 1. Poznań 1852.

Akta Aleksandra króla polskiego, wielkiego księcia litewskiego itd. (1501-1506). Wyd. F. PAPÉE. Kraków 1927.

Bielski M.: Kronika polska Marcina Bielskiego. Kraków 1597.

BIELSKi M.: Kronika wszystkiego świata. Kraków 1551.

Cudzoziemcy o Polsce. Relacje i opinie. Wybrał i oprac. J. Gintel. T. 1: Wiek X-XVII. Kraków 1971.

DaniŁowicz I.: Skarbiec dyplomatów papieskich, cesarskich, królewskich. T. 2. Wyd. J. SidoROWICZ. Wilno 1862.

Dary królewskie dla kościoła i klasztoru Augustianów w Krakowie. Oprac. W. KolaK. „Krakowski Rocznik Archiwalny" 2001, T. 7.

Dochody i wydatki konwentu braci eremitów św. Augustyna przy kościele św. Katarzyny w Kazimierzu. Wyd. J. Jelonek-Litewka, W. Kolak, C. Pirożyński, Z. Wojas. T. 1: $1502-$ 1505. Kraków 2002.

JAN z Komorowa: Kronika Zakonu Braci Mniejszych Obserwantów (1209-1536). Tłum. K. Żuchowski. Kalwaria Zebrzydowska 2014.

JAN z Komorowa: Memoriale Ordinis Fratrum Minorum a fr. Ioanne de Komorowo compilatum. Ed. X. Liske, A. Lorkiewicz. W: Monumenta Poloniae Historica. T. 5. Lwów 1888.

Joannis Dlugossii Annales seu cronicae incliti Regni Poloniae. Lib. 12. Cracoviae 2003-2005.

JoDCZyK K.: Opisy parafii diecezji wileńskiej z 1784 roku. T. 1: Dekanat Brasław. Białystok 2009.

Kopiarz rzymski Erazma Ciołka z pocz. wieku XVI-go. Oprac. S. KutrzebA, J. FiJAŁeK. „Archiwum Komisji Historycznej Polskiej Akademii Umiejętności” 1923, Seria 2, T. 1.

Kroniki Bernarda Wapowskiego z Radochoniec kantora katedr. krakowskiego. Część ostatnia, czasy podtugoszowe obejmująca 1480—1535. Wyd. J. SzUJSki. W: Scriptores rerum Polonicarum. T. 2. Kraków 1872.

Lietuvos didžiojo kunigaikščio Aleksandro Jogailaičio dvaro sąskaitu knygos (1494-1504). Parengè D. Antanavičıus, R. Petrauskas. Vilnius 2007.

Lietuvos Metrika (1427-1506). Knyga Nr. 5. Užrašymu knyga 5. Vilnius 1993.

Lietuvos Metrika. Knyga Nr. 1 (1380-1584). Užrašymu knyga 1. Vilnius 1998.

Lietuvos Metrika. Knyga Nr. 8 (1499-1514). Užrašymu knyga 8. Vilnius 1995.

Opisanie podróży Mikołaja von Popplau, rycerza rodem z Wrocławia. Tłum. P. RADZıKowski. Kraków 1996.

Podróż Ambrożego Kontaryniego przez Polskę do Persji 1474-1477. Tłum. J.U. Niemcewicz. W: K. Sienkiewicz: Skarbiec historii polskiej. T. 1. Paryż 1839.

Possevino A.: Moscovia. Tłum. A. Warkotsch. Warszawa 1988.

Prawa i przywileje miasta i dóbr ziemskich Zabłudów XV-XVIII w. Oprac. J. MARoszeK. Białystok 1994.

Scriptores rerum Polonicarum. T. 2. Kraków 1872.

StryנKOwsкi M.: Kronika polska, litewska, żmudzka i wszystkiej Rusi. T. 2. Warszawa 1846. Suszko H.: Latopis hustyński. Opracowanie, przekład i komentarze. Wrocław 2003. 
Teki A[dolfa] Pawińskiego. T. 1: Liber quitantiarum Alexandri regis ab a. 1502 ad 1506. Warszawa 1897.

Vetera monumenta Poloniae et Lithuaniae historiam illustrantia. T. 2. Ed. A. THEINER. Romae 1861.

Zbiór dawnych dyplomatow i aktow miast mińskiej gubernii, prawosławnych monasterów, cerkwi $i$ w różnych sprawach. Mińsk 1848.

Акты, относящиеся к истории Западной России. Т. 1: 1340-1506. Санктпетербург 1846. Акты, относящиеся к истории Западной России. Т. 2: 1506-1544. Санктпетербург 1848.

Акты, собранные в библиотеках и архивах Российской империи Археографической экспедииией. Т. 1: 1294-1598. Санктпетербургъ 1838.

Археографический сборник документов, относящихся к истории Северо-Западной Руси. Акты Виленской Комиссии для разбора древних актов. Т. 9. Вильна 1870.

Архивъ Юго-Зарадной Россіи, издаваемый Временною Коммиссіею для разбора древнихъ актовъ. Ч. 8. Т. 4. Кіевъ 1907.

Беларускі архіў. Т. 2: Літойская метрыка (XV-XVI ст.). Мінск 1928.

Летопись Никоновская. В: Словарь книжников и книжности Древней Руси. Т. 2 (вторая половина XIV-XVI в.). Ч. 2: Л-Я. Ленинград 1989.

Муханов П.А.: Сборник Муханова. [Акты по истории России за 1393-1729 г2.]. Москва 1836.

Памятники дипломатических сноченій древней Россіи съ державами иностранными. Ч. 1: Сношенія съ государствами европейскими. Памятники дипломатических сношеній съ имперіею Римскою. Т. 1: съ 1488 по 1594 годъ. С. Петербургъ 1851.

Полное собрание русских летописей. Т. 2. 1-е изд. Санктпетербургъ 1843.

Полное собрание русских летописей. Т. 5. Санктпетербургъ 1851.

Полное собрание русских летописей. Т. 6. Санктпетербургъ 1853.

Полное собрание русских летописей. Т. 8. Санктпетербургъ 1859.

Полное собрание русских летописей. Т. 12. С.-Петербургъ 1901.

Полное собрание русских летописей. Т. 24. Петроградъ 1921.

Полное собрание русских летописей. Т. 32. Москва 1975.

Русская историческая библиотека. Т. 27: Литовская Метрика. Отдел первый. Часть первая: Книги записей, т. 1. С.-Петербург 1910.

Сборник Императорского Русского Исторического Общества. Т. 35: Памятники дипломатических снотений Московского государства с Польско-Литовским. Т. 1: c 1487 по 1533 год. Ред. Г.Ф. КАРПОв. С.-Петербург 1882.

Собрание государственных и частных актов, касающихся истории Литвы и соединенных с ней владений [oт 1387 до 1710 года]. Ред. М. Крупович. Ч. 1. Вильно 1858.

Собраніе древних грамот и актов городов Вильны, Ковна и Трок, православных монастырей, церквей и по разным предметам. Т. 1. Вильна 1843.

\section{Opracowania}

BALIŃSKi M.: Historia miasta Wilna. T. 2. Wilno 1836.

Bartoszewicz J.: Helena Iwanowna, żona Aleksandra Jagiellończyka. W: J. Bartoszewicz: Studia historyczne i literackie. T. 1. Kraków 1880 (Dzieła Juliana Bartoszewicza, T. 8). 
Baumgarten N. DE: Généalogies des branches régnantes de Rurikides du XIIIe au XVIe siècle. Roma 1934.

Baumgarten N. DE: Généalogies et mariages occidentaux des Rurikides russes du Xe au XIIIe siècle. Roma 1927.

BIRKENMAJER L.: Zapiski historyczne wśród starych almanachów Biblioteki Jagiellońskiej. „Kwartalnik Historyczny” 1902, T. 16.

BŁAszczyK G.: Herbarz szlachty żmudzkiej. T. 2. Warszawa 2015.

BoJko K.: Stosunki dyplomatyczne Moskwy z Europą Zachodnia w czasach Iwana III. Kraków 2010.

Borkowska U.: Bracia mniejsi i prawosławie. W: Franciszkanie $w$ Polsce średniowiecznej. Cz. 1: Franciszkanie na ziemiach polskich. Red. J. KıoczowsKi. Kraków 1983.

Böttcher H.-J.: Christiane Eberhardine. Prinzessin von Brandenburg-Bayreuth, Kurfürstin von Sachsen und Königin von Polen, Gemahlin August des Starken. Dresden 2011.

Chodynicki K.: Kościół prawosławny a Rzeczpospolita Polska. Zarys historyczny 1370-1632. Warszawa 1934.

Chojnicka K.: Narodziny rosyjskiej doktryny państwowej. Zoe Paleolog — między Bizancjum, Rzymem a Moskwą. Kraków 2001.

Сномік P.: Trzej wileńscy męczennicy i początki monasteru św. Trójcy w Wilnie. „Studia Podlaskie" 2011, T. 19.

DALEwski Z.: Ceremoniat koronacyjny królów polskich w XV i początkach XVI wieku. „Kwartalnik Historyczny" 1995, T. 102.

DAlewski Z.: Władza - przestrzeń - ceremoniat. Miejsce i uroczystość inauguracji władcy w Polsce średniowiecznej do końca XIV w. Warszawa 1996.

Dróżdż A.J.: Tajemnice księgozbioru Iwana Groźnego. „Annales Academiae Paedagogicae Cracoviensis. Studia Ad Bibliothecarum Scientiam Pertinentia” 2001, T. 1.

Duczmal M.: Jagiellonowie. Leksykon biograficzny. Kraków 1996.

DworzaczeK W.: Genealogia. Tablice. Warszawa 1959.

FijaleK J.: Opisy Wilna aż do polowy wieku XVII-go [cz. 1]. „Ateneum Wileńskie” 1923, R. 1, nr 3-4.

FijaleK J.: Opisy Wilna aż do połowy wieku XVII-go [cz. 2]. „Ateneum Wileńskie” 1924, R. 2, nr 5-6.

FijaleK J.: Pierwszy synod diecezji wileńskiej w katedrze św. Stanisława 1520/21. „Kwartalnik Teologiczny Wileński” 1923-1924, R. 1-2.

Filimoniuk M.: Historia antiminsa a Boska Liturgia. „Wiadomości Diecezji Białostocko-Gdańskiej” 2005, nr 21 (55).

Folwarski H.: Erazm Ciołek. Biskup i dyplomata. Warszawa 1935.

Garbacik J.: Helena (1476-1513), żona Aleksandra Jagiellończyka. W: Polski słownik biograficzny. T. 9. Wrocław i in. 1960-1961.

Gloger Z.: Julian Bartoszewicz 1821-1870. W: Z. Gloger: Pisma rozproszone. T. 1: 18631876. Red. J. ŁAwski, J. LeoŃCZUK. Białystok 2014.

Hedemann O.: Historia powiatu brasławskiego. Wilno 1930.

Historia Kościoła w Polsce. T. 1. Cz. 1. Red. B. Kumor. Poznań 1974.

HoŁubowicz R.: Kanoniczna forma zawarcia małżeństwa w świetle Kodeksu Kanonów Kościołów Wschodnich. „Ius Matrimoniale. Ze studiów nad kościelnym prawem małżeńskim” 2013, T. 18 (24).

JoDkowski J.: Świątynia warowna na Kołoży $w$ Grodnie $w$ świetle badań archiwalnych $i$ archeologicznych dokonanych w 1935 r. Grodno 1936.

KarAmzin N.M.: Historya państwa rossyiskiego M. Karamzina. Tłum. G. BuCzyŃsKI. T. 5-6. Warszawa 1825-1826. 
Kempa T.: Wileńskie bractwo Św. Ducha jako centrum obrony prawosławia w Wielkim Księstwie Litewskim w końcu XVI i w pierwszej połowie XVII w. „Białoruskie Zeszyty Historyczne" 2004, T. 21.

Kijas A.: O. Antonio Possevino SJ o Rosji Iwana IV Groźnego. W: Antonio Possevino SJ (1533-1611). Życie i dzieło na tle epoki. Red. D. Quirini-PopŁAwsKA. Kraków 2012.

KolaK W.: Klasztor Augustianów przy kościele św. Katarzyny w Krakowie do połowy XVI wieku — fundacja, rozwój uposażenia i rola kulturalna. Kraków 1982.

KoneCZny F.: Litwa a Moskwa w latach 1449_1492. Wilno 1929.

Kordiukiewicz A.: Królowa Helena. „Biuletyn Informacyjny” 2012, nr 2 (56).

KraszewsKi J.I.: Wilno od początków jego do roku 1750. T. 1. Wilno 1838; T. 3. Wilno 1841.

KrupsKA A.: Z dziejów tworzenia się nowego układu politycznego $w$ Europie Wschodniej po upadku Złotej Ordy w XV wieku. „Roczniki Historyczne” 1976, T. 42.

Kuligowski J.: Kościól Wschodni na Ziemi Chełmskiej i południowym Podlasiu od chrystianizacji do końca XVI wieku. „Rocznik Mazowiecki” 2000, T. 12.

Limanowski M.: Szczątki Aleksandra Jagiellończyka w katedrze wileńskiej. „Ilustrowany Kurier Codzienny" z 26 listopada $1931 \mathrm{r}$.

Łatyszonek O.: Polityczne aspekty przedstawienia średniowiecznych dziejów ziem białoruskich $w$ historiografii Wielkiego Księstwa Litewskiego w XV-XVI w. „Białoruskie Zeszyty Historyczne. Беларускі гістарычны зборнік” 2006, Т. 25.

Maciszewska M.: Klasztor bernardyński w społeczeństwie polskim 1453-1530. Warszawa 2001.

Malaszewski D.: Niektóre aspekty życia monastycznego na terenie diecezji włodzimiersko-brzeskiej do końca XVI wieku. W: Życie monastyczne w Rzeczypospolitej. Red. A. Mironowicz, U. Pawluczuk, P. Chомiк. Białystok 2001.

Manyś B.: Uroczystości rodzinne $w$ Wilnie $w$ czasach Augusta III (1733-1763). Poznań 2012.

Maroszek J.: Pogranicze Litwy i Korony w planach króla Zygmunta Augusta. Z historii dziejów realizacji myśli monarszej między Niemnem a Narwią. Białystok 2000.

Mazuś M.: Koncepcje ideologiczne „Moskwa - III Rzym” oraz „Kijów - II Jerozolima” w ujęciu porównawczym. „Slavia Orientalis” 2015, T. 64, nr 3.

Mironowicz A.: Cerkiew prawosławna w dziejach Rosji. W: Wprowadzenie do studiów wschodnioeuropejskich. T. 3: Rosja. Red. A. Mironowicz. Lublin 2013.

Mironowicz A.: Helena Iwanowna fundatorka cudownej bielskiej ikony Matki Bożej. W: Wszechnica Kultury Prawosławnej. T. 6. Red. A. KuźmA, J. Sмyк. Białystok 2009.

Mironowicz A.: Kościół prawosławny w dziejach dawnej Rzeczypospolitej. Białystok 2001.

Mironowicz A.: Kościół prawosławny w Polsce. Białystok 2006.

Mironowicz A.: Organizacja Kościoła prawosławnego w Rzeczypospolitej do końca XVIII wieku. W: Europa orientalis. Polska i jej wschodni sąsiedzi od średniowiecza po wspótczesność. Studia i materiaty ofiarowane profesorowi Stanisławowi Alexandrowiczowi w 65. rocznice urodzin. Red. nauk. Z. Karpus, T. Kempa, D. Michaluk. Toruń 1996.

Narbutt T.: Dzieje narodu litewskiego. T. 8. Wilno 1840.

PAPÉE F.: Aleksander Jagiellończyk. Kraków 1949.

PAPÉE F., rec.: Cereteli E., Elena Joannowna, welikaja kniaginia litowskaja, russkaja, korolewa polskaja. Biograficzeskij oczerk w swiazi s istoriej togo wremeni, S.-Peterburg 1898. „Kwartalnik Historyczny” 1900, T. 14.

PAProcki H.: Antimension (gr. antiminsion, słow. antimins). W: Encyklopedia katolicka. T. 1. Red. F. GRYGOLEWICZ [i in.]. Lublin 1985.

Peltz W.: Suwerenność państwa w praktyce i doktrynie politycznej Rusi Moskiewskiej (XIVXVI w.). Zielona Góra 1994. 
Pietkiewicz K.: Dwór litewski wielkiego księcia Aleksandra Jagiellończyka 1492-1506. W: Lietuvos valstybe XII-XVIII w. Vilnius 1997.

PIETKIEWicZ K.: Itinerarium króla Aleksandra Jagiellończyka 1492-1506. Warszawa 2016.

PietKiewicz K.: Wielkie Księstwo Litewskie pod rząami Aleksandra Jagiellończyka. Poznań 1995.

Polechov S.: Wielkie Księstwo Litewskie i Królestwo Polskie za czasów Jagietty i Witolda w latopisarstwie ruskim. „Zeszyty Naukowe Uniwersytetu Jagiellońskiego. Prace Historyczne" 2014, T. 141, z. 2.

PtaŚnIK J.: Obywatelstwo miejskie w dawnej Polsce. (Na tle stosunków Krakowa). „Przegląd Warszawski” 1921, R. 1, T. 1, nr 2.

Quirini-Poplawska D., Borkiewicz Ł.: Itinerarium ojca Antonia Possevivo SJ (1533-1611). W: Antonio Possevino SJ (1533-1611). Życie i dzieto na tle epoki. Red. D. Quirini-PoPŁAWSKA. Kraków 2012.

Radziukiewicz A.: Bielsk Heleny. Prawosławna królowa. „Przegląd Prawosławny” 2007, nr 7 (265).

Rękopisy supraskie $w$ zbiorach krajowych i obcych: katalog rękopisów supraskich. Oprac. A. Mironowicz [i in.]. Białystok 2014.

Rutкowska G.: Podróże polskich królowych z XV wieku. W: Samotrzeć, w kompanii czy z orszakiem? Społeczne aspekty podróżowania w średniowieczu i czasach nowożytnych. Red. M. SACZYŃSKA, E. WóŁKIEWICZ. Warszawa 2012.

RutKowska G.: Status wdów po królach polskich z dynastii Jagiellonów. W: Kobiety $i$ władza w czasach dawnych. Red. B. CzwoJdrak, A.A. KLuczeK. Katowice 2015.

SAwicki J.: Concilia Poloniae. Źródta i studia krytyczne. T. 3. Warszawa 1948.

Siemaszko A.: O historii monasteru supraskiego i jego bibliotece: uwagi do ksiażki: Rękopisy supraskie w zbiorach krajowych i obcych: katalog rękopisów supraskich, oprac. Antoni Mironowicz et al. wyd. Libra, Biatystok 2014, ss. 392. „Studia Podlaskie” 2014, T. 22.

Skibniewska J.: Dwór królewski Aleksandra Jagiellończyka w latach 1501-1506. Lublin 2015.

Stownik geograficzny Królestwa Polskiego. T. 6. Warszawa 1885; T. 13. Warszawa 1893.

Sosna G.: Cudowne ikony na Białostocczyźnie. „Elpis” 1999, T. 1, nr 1.

Sosna G.: Święte miejsca i cudowne ikony. Prawosławne sanktuaria na Białostocczyźnie. Białystok 2001.

SPIERALSKi Z.: Zofia Paleolog adresatka listu Kallimacha. „Odrodzenie i Reformacja w Polsce" 1978, T. 23.

Stankiewicz D.: Bielska ikona Bogurodzicy. „Над Бугом и Нарвою. Український часопис Підляшшя" 1994, № 5 (15).

Stasiak A.M., rec.: Z. Wojtkowiak, Aleksander Gwagnin i Maciej Stryjkowski dwaj autorzy jednego dzieła, Poznań 2015. „Roczniki Humanistyczne” 2016, T. 64, z. 2.

Surynowicz H.: Życie monastyczne na Grodzieńszczyźnie w XIX wieku. W: Życie monastyczne w Rzeczypospolitej. Red. A. Mironowicz, U. Pawluczuk, P. Сномiк. Białystok 2001.

TARANOwsKi T.: Historia prawa rosyjskiego. Cz. 1: Historia ustroju państwowego. Lwów 1928.

TĘGowski J.: Pierwsze pokolenia Giedyminowiczów. Poznań-Wrocław 1999.

Tomalska J.: Ikona Matki Bożej Hodegetrii z Brańska. Rozważania ikonograficzne. „Biuletyn Konserwatorski Województwa Podlaskiego" 2012, z. 18.

Trajdos T.M.: Metropolici kijowscy Cyprian i Grzegorz Camblak a problem Cerkwi prawosławnej w państwie polsko-litewskim u schyłku XIV i w pierwszej ćwierci XV w. „Balcanica Posnaniensia" 1985, T. 3.

Troc-Sosna A.: Gródecka ikona Matki Bożej. „Przegląd Prawosławny” 2002, nr 2 (200).

Walejкo K. [i in.]: Praktyczny przewodnik po Wilnie. Suwałki 2003. 
WiniarsKa A.: Rola Heleny Rurykowiczówny w świetle stosunków litewsko-moskiewskich na przełomie $X V$ i XVI w. „Rocznik Naukowo-Dydaktyczny WSP w Krakowie. Prace Historyczne" 1968, T. 4.

Wojtкоwiak Z.: Aleksander Gwagnin i Maciej Stryjkowski dwaj autorzy jednego dzieła. Poznań 2015.

WолткошіАк Z.: Dyplomatyka a polityka litewska w końcu XV wieku. „Acta Baltico-Slavica” 1976, T. 9.

WolfF J.: Kniaziowie litewsko-ruscy od końca czternastego wieku. Warszawa 1895.

ZielińsKa-Klimkiewicz Z.: Księozbiór Bartoszewiczów - przeszłość i teraźniejszość. „Acta Universitatis Lodziensis. Folia Librorum" 1998, T. 8.

БЕРеЖков М.Н.: Елена Ивановна, великая княгиня литовская и королева польская. В: Труды ІХ археологическаго съезда въ Вильне 1893. Т. 2. Москва 1897.

ГильтеБРАндт П.: Рукописное отделение Виленской публичной библиотеки, вып. 1: I - Церковно-славянские рукописи, II - Русские пергамены. Вильна 1871.

ЕлАгин Н.: Елена Иоанновна, великая княгиня Литовская и королева Польская. „Журнал Министерства народного просвещения” 1846, Т. 50, № 4, отд. 2.

ЗАБелин И.Е.: Домашний быт русского народа в XVI и XVII cm. Т. 1: Домашний быт русских иарей в XVI и XVII cm. Москва 1895; Т. 2: Домашний быт русских иарии в XVI и XVII cm. Москва 1901.

Золтан А.: К предыстории русск. «государь». В: Из истории русской культуры. Т. 2. Москва 2002.

История Русской православной Церкви в документах региональных архивов России. Ред. Архимандрит И. Просвирнин. Москва 1993.

КАРАмзин Н.М.: История государства Российского. Т. 5-6. Москва 1818.

КАРТАШЕВ А.В.: Очерки по истории русской церкви. Париж 1959.

Клосс Б.М.: Никоновский свод и русские летописи XVI-XVII веков. Москва 1989.

КонтАРини А.: Путешествие в Персию. Подгот. текста, пер. и коммент. Е.Ч. СкРжинской. В: Барбаро и Контарини о России: К истории итало-российских связей в XV в. Ленинград 1971.

Кром М.М.: Меж Русью и Литвой. Пограничные земли в системе русско-литовских отношений концуа XV - первой трети XVI в. Москва 2010.

Лурье Я.С.: Елена Ивановна, королева Польская и великая княгиня Литовская как писатель-публицист. „Canadian-American Slavic Studies” 1979, Vol. 13, no 1-2.

Петров А.С.: Шитый образ под иконой. Изображения на подвесных пеленах. В: Церковное иитьё в Древней Руси. Ред. Э.С. Смирнов. Москва 2010.

САПунов А.: Древние иконы Богоматери в Полоикой епархии. Витебск 1888.

Скрынников Р.Г.: Иван III. Москва 2006.

Хорошкевич А.Л.: Жалованые грамоты Литовской метрики кониа XV века и их классификация. В: Источниковедеческие проблемы истории народов Прибалтики. Ред. П. Крастынь. Рига 1970.

Хорошкевич А.Л.: Русское государство в системе международных отношений конца XV - начала XVI в. Москва 1980.

ЦеРетЕли Е.: Елена Иоанновна великая княгиня литовская, русская, королева полская. С. Петербургъ 1898.

ШАлина И.А.: Икона Богоматери Одигитрии - древняя икона Полоикого Софийского собора. В: Сборник статей: К 60-летию со дня рождения Валентина Александровича Булкина. Санкт-Петерург 1999. 


\section{Grażyna Rutkowska}

\section{Church in the life of Helen of Moscow, the wife of Alexander the Jagiellonian}

Summary

The article aims to present personal piety and the religious practices of the daughter of the Grand Duke of Moscow Ivan III, Helen of Moscow (1476-1513). Her mother was also the Byzantine duchess Zoe. In 1495 Helen married the Grand Duke of Lithuania Alexander the Jagiellonian, who later became king of Poland. The sources inspected in order to present the topic were documents and letters from the period, the chronicles of some more important historiographers who published after Jan Długosz (Bernard Wapowski, Maciej of Miechów, Marcin Bielski, Marcin Kromer, Maciej Stryjkowski, and Jan of Komorów) and the records from selected chronicles (Sophia Chronicle I, Chronicle of Bychowiec, Chronicle of Huštýn). At first the role of Orthodox Christianity in the doctrine of the Great Duchy of Moscow is discussed. What follows is a discussion of how Helen was brought up in the Moscow court and what the European and Polish customs were in terms of dynastic marriages with Orthodox Christians. Then the question of Helen's liberty in practicing Orthodox Christianity in Lithuania and Poland is analyzed. Examples are also provided of her donations to Orthodox churches and monasteries in the Grand Duchy of Lithuania. At the end of the study, Helen's relations with Catholic church are discussed, for example the debate over the possibility of the queen converting to Roman Christianity and of her second baptism within this religious denomination.

Key words: Helen of Moscow, Alexander the Jagiellonian, Orthodox Christianity, Catholicism versus Orthodox Christianity, religiousness at court

\section{Grażyna Rutkowska}

\section{Die Rolle der Kirche im Leben Helenas von Moskau,} der Ehegattin von Alexander dem Jagiellonen

\section{Zusammenfassung}

Im vorliegenden Artikel wird der Versuch unternommen, persönliche Frömmigkeit und die Ausübung religiöser Praktiken von Helena von Moskau (1476-1513), Tochter des Großfürsten von Moskau Iwan III. und der byzantinischen Prinzessin Zoë, die 1495 mit dem Großfürsten von Litauen, Alexander dem Jagiellonen, dem späteren König von Polen vermählt wurde, darzustellen. Hierzu wurden die Urkunden und Korrespondenz aus der Epoche, Chroniken der bedeutendsten Geschichtsschreiber nach Jan Długosz (Bernard Wapowski, Matthias de Miechow, Marcin Bielski, Martin Cromer, Maciej Stryjkowski und Johannis de Komorowo), sowie die Überlieferungen ausgewählter Annalen (Erste Chronik von Sofia, Chronik von Bychowiec und Chronik von Hustynja) in Anspruch genommen. Zuallererst wurde die Rolle der orthodoxen Kirche in der Doktrin des Großfürstentums Moskau, die Erziehung Helenas am Moskauer Hof und die in Europa und Polen geltenden, auf dynastische Ehen mit Bekennern des orthodoxen Glaubens bezogenen Sitten und Gebräuche erörtert. Im weiteren Teil des Beitrags wurde die 
Frage der Religionsfreiheit Helenas bei der Ausübung orthodoxer Praktiken in Litauen und Polen behandelt. Darüber hinaus wurden die Beispiele ihrer Schenkungen an orthodoxe Kirchen und Klöster im Großfürstentum Litauen aufgeführt. Zum Abschluss wurde das Verhältnis Helenas zur katholischen Kirche erörtert (u.a. der Streit über eventuelle Notwendigkeit des Glaubenswechsels durch die Königin und deren erneute Taufe im lateinischen Ritus).

Schlüsselwörter: Helena von Moskau, Alexander der Jagiellone, orthodoxe Kirche, Katholizismus, höfische Religiosität 